\title{
WestVirginiaUniversity
}

THE RESEARCH REPOSITORY @ WVU

Graduate Theses, Dissertations, and Problem Reports

2005

\section{Levels of stress and coping in certified athletic training graduate assistants}

Darya C. Feldman

West Virginia University

Follow this and additional works at: https://researchrepository.wvu.edu/etd

\section{Recommended Citation}

Feldman, Darya C., "Levels of stress and coping in certified athletic training graduate assistants" (2005). Graduate Theses, Dissertations, and Problem Reports. 2180.

https://researchrepository.wvu.edu/etd/2180

This Thesis is protected by copyright and/or related rights. It has been brought to you by the The Research Repository @ WVU with permission from the rights-holder(s). You are free to use this Thesis in any way that is permitted by the copyright and related rights legislation that applies to your use. For other uses you must obtain permission from the rights-holder(s) directly, unless additional rights are indicated by a Creative Commons license in the record and/ or on the work itself. This Thesis has been accepted for inclusion in WVU Graduate Theses, Dissertations, and Problem Reports collection by an authorized administrator of The Research Repository @ WVU. For more information, please contact researchrepository@mail.wvu.edu. 
Levels of Stress and Coping in Certified Athletic Training Graduate Assistants

\author{
Darya C. Feldman
}

\begin{abstract}
Thesis submitted to the
School of Physical Education

at West Virginia University

in partial fulfillment of the requirements

for the degree of
\end{abstract}

\author{
Master of Science \\ in \\ Athletic Training
}

\author{
Michelle A. Sandrey, Ph.D., ATC, Chair \\ Edward Etzel, Ed.D. \\ Vincent G. Stilger, HSD, ATC
}

School of Physical Education

Morgantown, West Virginia

2005

Keywords: stress, burnout, coping strategies, certified athletic trainer 


\begin{abstract}
Levels of Stress and Coping in Certified Athletic Training Graduate Assistants
\end{abstract}

Darya C. Feldman

Objective: The purposes of the study were to identify the stress levels of certified athletic training graduate assistants their coping responses. Design: First design was a prospective descriptive study on stress levels and coping strategies between gender and graduate assistant status ( $1^{\text {st }}$ or $2^{\text {nd }}$ year). The second design was a $2 \mathrm{X} 2$ factorial design of graduate assistant status and gender. The dependent variables were academic, social, financial, overall stress levels and overall stress levels now compared to last year. Participants: 1,000 certified student members of the NATA were e-mailed to participate, 207 questionnaires were returned. Interventions: The questionnaire battery consisted of the Quick Stress Questionnaire (QSQ), the Brief COPE Questionnaire (BCQ), and 17 demographic questions used to gather responses. Results: There were no significant differences between gender and graduate assistant status for the five stressors. Conclusion: Females reported higher stress levels than males. Responses were more positive than negative in regards to coping strategies. 


\section{AKNOWLEDGEMENTS}

First and foremost I need to thank my family for keeping me motivated and encouraging me along the way. I would never have made it this far if it was not for your undying support through these years. Mom and Dad thank you for being the best parents anyone can ask for and the endless hours on the phone reminding me that this will payoff in the end. Erin, the greatest sister, thank you for being my copy editor for everything I have written and continually making me laugh.

Patti thank you for being the best roommate, classmate, and friend over these past two years. You always kept me on task and kept me laughing at everything even in the most stressful times. Dee, you also kept me going and continually reminded me that I will be better off after this.

Dr. Sandrey, my thanks to you for your patience in our countless revision meetings and the continual push to be better. Also thanks for instilling in me the drive to always ask the questions why when we do something in our profession.

Thank you Dr. Ed Etzel and Dr. Vince Stilger for so graciously being on my committee during these busy and stressful times. 


\section{TABLE OF CONTENTS}

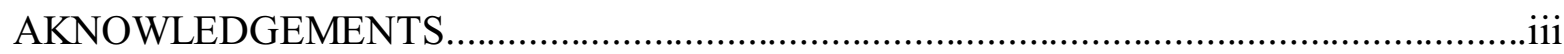

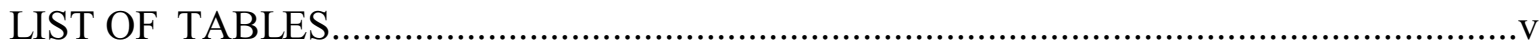

INTRODUCTION

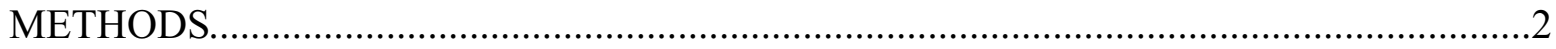

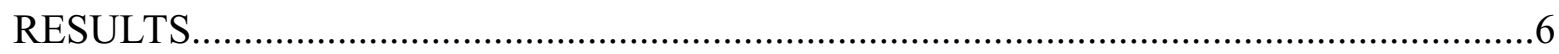

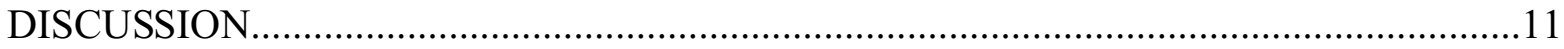

CONCLUSION

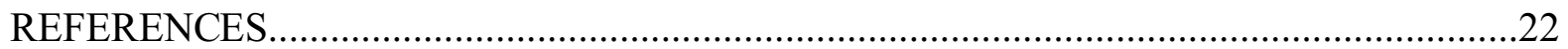

APPENDICES

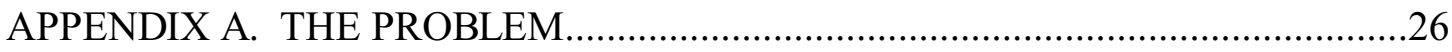

APPENDIX B. LITERATURE REVIEW...........................................................30

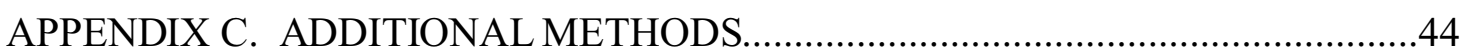

APPENDIX D. ADDITIONAL RESULTS..............................................................5

APPENDIX E. RECOMMENDATIONS FOR FUTURE RESEARCH........................71

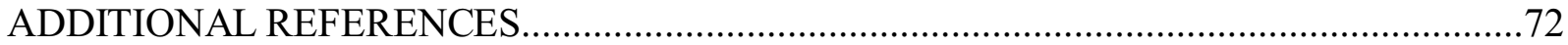


Table

\section{LIST OF TABLES}

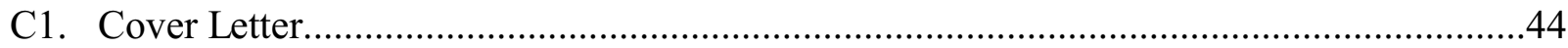

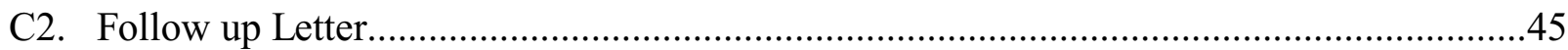

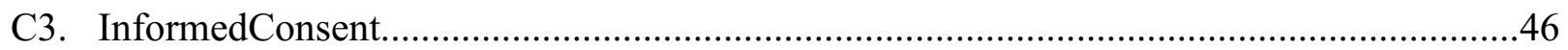

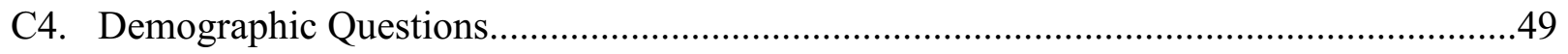

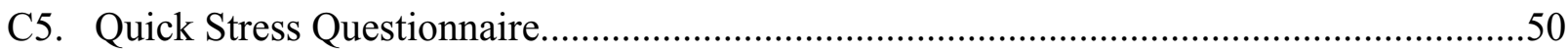

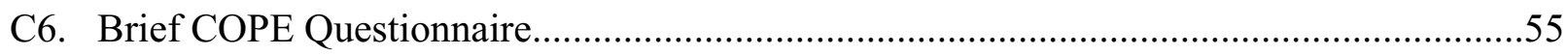

D1. Demographic Information descriptive statistics for credit hours...................................58

D2. Demographic Information descriptive statistics for athletic training assignment..............58

D3. Demographic Information descriptive statistics for contract hours per week..................59

D4. Demographic Information descriptive statistics for actual worked hours per week..........59

D5. Demographic Information descriptive statistics for travel time (min).........................60

D6. Demographic Information descriptive statistics for number of sports to cover................60

D7. Demographic Information descriptive statistics for number of assistants......................60

D8. Demographic Information descriptive statistics for the participants stipend....................61

D9. Demographic Information descriptive statistics for how the stipend was received............61

D10. Demographic Information descriptive statistics for hours per week of exercise.............61

D11. Demographic Information descriptive statistics for hours spent studying.....................62

D12. Demographic Information descriptive statistics for hours doing leisure activities.........62

D13. Descriptive Statistics for Quick Stress Questionnaire Responses (5 main stressors)......63

D14. Descriptive Statistics for Quick Stress Questionnaire Responses (remaining stressors)....63 
D15. Brief COPE Questionnaire Results

D16. Descriptive Statistics for gender x class rank for Academic or work concerns..............66

D17. Descriptive Statistics for gender x class rank for Social/Personal Relationships.............66

D18. Descriptive Statistics for gender x class rank for Financial Concerns...........................66

D19. Descriptive Statistics for gender x class rank for Overall level of stress.......................66

D20. Descriptive Statistics for gender x class rank for Overall stress

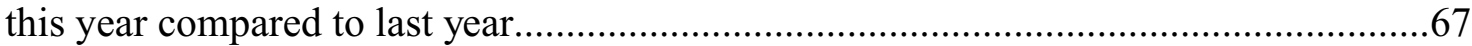

D21. Descriptive Statistics for Gender and five main stressors.........................................67

D22. Descriptive Statistics for First year and Second year graduate assistant and five main stressors

D23. Descriptive Statistics for Gender and remaining QSQ stressors 68

D24. Descriptive Statistics for $1^{\text {st }}$ year $2^{\text {nd }}$ year graduate assistant and remaining QSQ stressors

D25. Between Subjects MANOVA for the Quick StressQuestionniare. 


\section{INTRODUCTION}

Stress is a phenomenon that affects everyone. The definition is never absolute and has been defined in many different ways. Rabin ${ }^{1}$ described stress as a condition in which there is a marked perceived discrepancy between demands on an individual and the individual's ability to respond. Additionally stress can be described as the interaction between stressors and the individual along with how the individual reacts to the stressors. ${ }^{2}$ Gieck $^{3}$ describes stress as the individual's physical and emotional reaction to demands placed on him. Dewe ${ }^{4}$ suggests that stress is what arises from those situations in which the individual perceives are about to tax his/her physical or emotional resources. Everyone's reaction to stress will differ. Some people will react in a positive manner, which is using stress as a motivational tool, or in a negative manner, which can lead to chronic stress and burnout. Chronic stress can happen to anyone in any profession. Burnout is a reaction to chronic stress that involves negative interactions between environmental and personal characteristics, and as a chronic condition that develops when one is working too hard for too long in a high-pressure situation. " "One can experience stress without burnout, but not burnout without stress. ${ }^{\circ 6}$

Compared to other allied health professionals, athletic training appears to have one of the lowest burnout rates. ${ }^{7}$ Of the studies that exist, most have focused on full time certified athletic trainers. ${ }^{3,5-11}$ Results from those studies indicated that stress levels exist, and were either lower than other professions, ${ }^{7}$ or if lower levels of hardiness and social support and higher levels of athletic training issues were evident, higher levels of stress were experienced. ${ }^{5}$ On the other hand, little research has been conducted on stress levels for undergraduate ${ }^{12}$, graduate athletic training students ${ }^{13}$, and certified athletic training graduate assistants. It can be hypothesized that 
since both groups of students are preparing to advance in the profession and both are exposed to the same type and levels of stress similar to full time certified athletic trainers, that the results from these studies would be similar. Although graduate athletic training students are exposed to supervision and additional responsibilities not experienced by undergraduate students, the studies indicated that stress levels are more similar to other college students, ${ }^{14-19}$ or students in nursing, ${ }^{1,4,20-25}$ medicine, ${ }^{1,26-29}$ and physical therapy fields. ${ }^{30-31}$

Only one study has been completed on the stress and coping responses of certified graduate athletic training students in a post-certification masters program. ${ }^{13}$ There have not been any studies completed on certified athletic training graduate assistants. The graduate assistant is attending a masters program full-time and working at their clinical athletic training assignment, accruing hours which may be above the minimum required of 20 hours per week. Due to the academic load and work hours graduate assistants are under considerable amounts of stress. The purposes of the study were to identify the levels of stress of certified athletic training graduate assistants and the coping responses of the graduate assistants.

\section{METHODS}

The design was a prospective descriptive study of existing groups to describe and compare stress levels and coping strategies between a first year graduate assistant and a second year graduate assistant, and between gender. The second design was a $2 \mathrm{X} 2$ factorial design. The two independent variables were 1) graduate assistant (first year or second year graduate assistant) and 2) gender (male or female). The five dependent variables for both designs were financial concerns, academic concerns, social concerns, overall level of stress, and stress level compared to one year ago as measured by the QSQ. 
Subjects

Participants in this study were certified student members from the National Athletic Trainers Association (NATA). One thousand participants were sent the email questionnaire battery through the NATA membership and information technology department. Of those 1,000, 207 returned the questionnaire battery for a return rate of $20.7 \%$. These participants were sent the questionnaires again two weeks after the initial email as a reminder to complete the study. This study was approved by the Institutional Review Board (IRB) for protection of human subjects at West Virginia University.

Instrument

The questionnaires consisted of a 25-item Quick Stress Questionnaire (QSQ), 28 item Brief COPE, and 17 demographic questions for general information. The QSQ uses a nine-point Likert scale ranging from 1 (little stress) to 9 (extreme stress) to measure sources of stress and stress-related symptoms. The respondents rated the severity of eight potential areas of stress (e.g., academic, social/personal, family, financial, self-image, health, sexual, day-to-day hassles) on their lives, and identified the types and degrees to which they experienced various stress-related symptoms. Support for the QSQ's construct validity has been established through Maximum Likelihood Factor Analysis (MLFA), which revealed that the nine-stress source items were loaded on a single stress source factor. Cognitive, somatic, and behavioral factors using Omega coefficient estimates of internal validity were observed to be $.89, .83$, and .79 , respectively. ${ }^{32}$

The Brief COPE Questionnaire (BCQ) consisted of 28 questions, which measure 14 conceptually differentiable coping reactions. Some are adaptive, others problematic. The BCQ 
is a derivative of the full inventory COPE questionnaire. The items can be used in retrospective and concurrent situational format or dispositional format. ${ }^{33}$ The BCQ uses a four-point Likert scale ranging from 1 (I haven't been doing this at all) to 4 (I've been doing this a lot).

Internal structure of the $\mathrm{BCQ}$ was evaluated using an exploratory factor analysis on the item set using an oblique rotation to permit correlations. Nine factors had eigen values greater than 1.0 which accounted for $72.4 \%$ of the variance in responding. Results indicated that the structure was conceptually consistent to that reported for the full inventory. Analysis produced reliabilities at or above $.50(\mathrm{a}=.50-.90)$, which supported the internal validity of the abbreviated scales. ${ }^{33}$ The questionnaire was estimated to take about 5-10 minutes to complete.

A demographic questionnaire was created by the primary investigator, asking questions related to credentials, academic, clinical assignment, and activity. Peers in the athletic training field and an individual with experience in psychometrics and writing questionnaires reviewed the questionnaire for improvements on the understanding of the questions and for suggestions of questions that may have been forgotten. The whole battery of questionnaires took about 20-30 minutes to complete.

Procedures

The NATA membership/information technology department was contacted prior to data collection to inquire about email addresses of certified student members. As a service to NATA members, the questionnaire battery was sent via e-mail to the certified student members through the National Athletic Trainer's Association (NATA) membership/information technology department. The e-mail consisted of a cover letter (Tables C1 and C2) explaining what the student should do if willing to participate. Each of the students were then assigned a password 
and asked to visit a website where the consent form (Table C3) and questionnaires (Tables C4, C5, C6) were located. If willing to participate, the student then typed in their password, answered the questionnaire, and returned it by clicking the submit button. If the student was not willing to participate, they simply did not return the questionnaire to the researcher. The graduate students who did not participate within two weeks were contacted a second time and once again asked to participate. The questionnaire was emailed once in the month of February and then two weeks following, which turned out to be the first week in March. The data was returned to the researchers via an email that was addressed as anonymous for the confidentiality of the participants. The information that was returned was then put into a spreadsheet for future analysis using SPSS for Windows (version 12.0; SPSS, Inc. Chicago, IL).

\section{Protection of Web-based Data}

The only instrument was a questionnaire sent via email to the certified students. The online questionnaire was housed on the university server, which, by using a firewall, protects data in transit from outside observation. The results of each questionnaire were automatically processed by a CGI server, which was also protected by the firewall and was accessible only to two university web masters. The data was processed in the working memory of the CGI server and was not stored to disk; after being processed the data no longer exists on the CGI server. The CGI server automatically sends the data via e-mail to the researcher where they were saved in a locked file. Upon completion of data collection, the spreadsheet was transferred to a disk that was kept in a locked drawer and the data was then deleted from the researcher's e-mail account. 


\section{Statistical Analysis}

Descriptive statistics included percentages of responses for the demographic and Brief COPE responses. A two way Multivariate Analysis of Variance (MANOVA) was performed to determine the main effects and interaction for gender and graduate assistant position. A probability level of $\mathrm{p}<0.05$ was set for all tests. Statistical analysis was conducted using SPSS for Windows (version 12.0; SPSS, Inc. Chicago, IL).

\section{RESULTS}

Demographic Information

Ninety eight and one tenth percent of the participants $(n=203)$ chose the NATABOC certification as their primary certification. Only $1.4 \%(n=3)$ also have the CSCS certification and only one person chose no response (.5\%). One year graduate programs make up 5.8\% $(n=12)$ of the programs with $90.3 \%(n=187)$ comprising two year programs, and $3.9 \%(n=8)$ did not respond. Graduate students received a partial tuition waiver $(17.4 \%, n=36)$, full tuition waiver $(65.7 \%, n=136)$, no tuition waiver $(16.4 \%, n=34)$, and there was one $(.5 \%)$ no response. Sixty one and eight tenths percent $(n=128)$ have a research project or thesis required for their program, while $36.2 \%(n=75)$ do not and $1.4 \%(n=3)$ gave no response. For the participants current semester credit hours, the most frequently reported was 9 credits $(39.6 \%, n=82)$ with the remaining credit hours found in Table D1. Fifty four and one tenth percent $(n=112)$ of the participants reported their course load to be moderate, $24.2 \%(n=50)$ reported a heavy course load, $19.3 \%(n=40)$ reported having a light course load, and $2.4 \%(n=5)$ gave no response.

For their athletic training assignment $60.9 \%(n=126)$ were assigned to a college with the remaining choices in Table D2. The mean for contract required hours per week was $21.68 \pm$ 
8.69. The largest percentage of the required contract hours were $58.1 \%(\mathrm{n}=104)$ for 20 hours. The remaining contract hour responses can be found in Table D3. The average hours per week that was spent at their clinical sites was $37.84 \pm 13.54$ hours. The actual hours worked per week were 40 hours $(18.2 \%, \mathrm{n}=37), 30$ hours $(17.2 \%, \mathrm{n}=35), 35$ hours $(13.8 \%, \mathrm{n}=28), 50$ hours $(7.4 \%$, $\mathrm{n}=15$ ), with the remaining number of hours found in Table D4. Travel time averaged $14.04 \pm$ 12.83 minutes and $27.7 \%(\mathrm{n}=54)$ had a travel time of 5 minutes. The remaining travel times are found in Table D5. The mean number of sports the participants covered was $4.90 \pm 6.46$ sports with $27.5 \%(\mathrm{n}=49)$ having 2 sports to cover with the rest listed in Table D6.

The mean number of assistants working with the graduate assistant was $1.34 \pm 1.88$ and having no assistants was the most frequent response of $47.3 \%(n=78)$ with the rest listed in Table D7. The majority of the stipends were $\$ 6000$ - 8999 for 30.4\% ( $\mathrm{n}=63$ )and the remaining can be found in Table D8. Of that stipend $61.8 \%(\mathrm{n}=128)$ received it monthly with those remaining responses listed in Table D9.

Hours spent per week exercising was $4.78 \pm 3.27$ hours. The amount of hours of exercise per week ranged from 0 hours to 15 hours per week. Refer to Table D10 for the breakdown of those hours. The hours spent per week studying are $9.12 \pm 7.24$ hours. Hours spent studying per week ranged from 0 to 40 hours per week with the highest percentage at 10 hours $(16.8 \%, n=34)$. Refer to Table D11 for the breakdown of those hours. Hours per week spent on leisure activities was $7.93 \pm 5.84$ hours. There was a range from 0 to 36 hours with the highest percentage at 10 hours $(20.6 \%, \mathrm{n}=41)$. Refer to Table D12 for the breakdown of leisure activity hours. Quick Stress Questionnaire

The Quick Stress Questionnaire responses have been broken down into two tables (Table 
D13 and Table D14). The first table (D13) includes the responses for the five main stresses that were used in the MANOVA statistical analysis. The second table (D14) includes the remaining stresses on the QSQ. Responses on the 9 point Likert scale are grouped into three categories of little (choices 1 to 3 ), moderate (choices 4 to 7 ), and extreme (8 to 9).

All of the five main stress responses had a majority of the moderate category chosen. These include academic or work concerns, social/personal relationships, financial concerns, overall level of stress at this time, and overall level of stress this year as compared to last year. Academic or work concerns stress did have the highest percentage $(70.6 \%, \mathrm{n}=146)$ compared to the other four stresses. (Table D13)

Ten of the remaining 18 stresses had the little category chosen the most. Those include health concerns, sexual concerns, feelings of depression (hopelessness, powerless, and/or poor self esteem), indigestion (stomachache, diarrhea, ulcer attacks, constipation, and/or colitus), tics (tremors and/or muscle spasms), sleeping disturbances (insomnia, oversleeping, night awakening, and/or troublesome dreams), disordered eating (overeating and/or undereating), excessive drinking and/or drug use, hypertension, and acne (eczema, hives, breaking out, and/or skin blotching and skin blanching). Of those stresses, tics, tremors, and muscle spasms had the highest percentage $(81.1 \%, \mathrm{n}=168)$ of responses in the little category. The remaining eight stresses that had the moderate category chosen the most were family concerns, self-image, day to day hassles, anger (hostility, irritability, and/or resentment), apprehension (fears and/or worrying), muscle tension (headaches, backaches, and/or muscle aches), forgetfulness (mental inefficiency, inability to study, and/or lack of motivation), and avoidance behavior (procrastination, escapism, TV watching, excessive partying, class cutting, absenteeism). Of 
those eight stresses, day to day hassles had the highest percentage $(64.3 \%, \mathrm{n}=133)$ of responses in the moderate category. (Table D14)

\section{Brief COPE Questionnaire Responses}

The Brief COPE questionnaire response choices ranged from 1 through 5 and are in order as follows where 1 is "I haven't been doing this at all," 2 and 3 are in between with no specific word value, 4 is "I've been doing this a lot, and 5 is no response." Of the four response choices (not including the no response option), the greatest number of responses were for selection number one. Those questions were $\# 11(40.1 \%, \mathrm{n}=83), \# 12(42.5 \%, \mathrm{n}=88), \# 19(81.2 \%, \mathrm{n}=168)$, \#20 (80.2\%, n=166), \#21 (47.8\%, n=99), \#23 (66.7\%, n=138), \#24 (72.5\%, n=150), \#25 (64.3\%, $\mathrm{n}=133)$, \#26 (70.5\%, $\mathrm{n}=176)$, and \#28 (49.8\%, n=103). In summary, the majority of the participants have not been using religion, denial, venting, substance use, behavioral disengagement, or self blame to deal with their stress, respectively.

Seven of the questions had response number two selected for the following. Those were \#4 (29.5\%, n=61), \#10 (28\%, n=58), \#15 (29\%, n=60), \#16 (34.8\%, n=72), \#17 (30\%, n=62), $\# 22$ (39.1\%, $n=81)$, and \#27 (32.4\%, $n=67)$. The coping techniques for these questions are related to planning, humor, using instrumental support, self distraction, venting, and self blame, respectfully. Participants are selecting response number two, but are not relying heavily on these techniques.

Ten of the questions had response number three selected most frequently. Those were for questions \#1 (31.9\%, n=66), \#2 (35.3\%, n=73), \#3 (34.3\%, n=71), \#7 (37.2\%, n=77), \#8 (34.8\%, n=72), \#9 (28\%, n=58), \#13 (32.9\%, n=68), \#14 (30.9\%, n=64), \#17 (30\%, n=62), and $\# 18(31.4 \%, \mathrm{n}=65)$. Number 17 had an equal percentage for responses $\# 2$ and $\# 3$. The coping 
responses that correspond to the questions are active coping, planning, acceptance, humor, using emotional support, and self distraction, respectively. Even though response \#3 has no specific word value it is something that the participants might be using as a coping strategy.

Only two questions had response \#4 (I'm doing this a lot) chosen the most. These questions were $\# 5(30 \%, \mathrm{n}=62)$ and $\# 6(35.7 \%, \mathrm{n}=74)$. Both of these questions correspond with positive reframing. The remaining responses are listed in Table D15. MANOVA Results

The descriptive statistics are listed in Tables D16 - D20. There was no significant difference for gender for academic $\left(\mathrm{F}_{1,206}=.531, \mathrm{P}=.589, \mathrm{ES}=.005, \beta=.137\right)$, social $\left(\mathrm{F}_{1,206}=\right.$ $.188, \mathrm{P}=.829, \mathrm{ES}=.002, \beta=.079)$, financial concerns $\left(\mathrm{F}_{1,206}=.431, \mathrm{P}=.662, \mathrm{ES}=.004, \beta=\right.$ $.116)$, overall level of stress $\left(\mathrm{F}_{1,206}=.285, \mathrm{P}=.752, \mathrm{ES}=.003, \beta=.095\right)$, and overall level of stress as compared to one year ago $\left(\mathrm{F}_{1,206}=.844, \mathrm{P}=.431, \mathrm{ES}=.008, \beta=.194\right)$.

There was no significant difference for first year or second year graduate assistant for academic $\left(\mathrm{F}_{1,206}=1.843, \mathrm{P}=.161, \mathrm{ES}=.018, \beta=.381\right)$, social $\left(\mathrm{F}_{1,206}=1.431, \mathrm{P}=.241, \mathrm{ES}=\right.$ $.014, \beta=.304)$, financial concerns $\left(\mathrm{F}_{1,206}=.282, \mathrm{P}=.755, \mathrm{ES}=.003, \beta=.094\right)$, overall level of stress $\left(\mathrm{F}_{1,206}=.415, \mathrm{P}=.661, \mathrm{ES}=.004, \beta=.117\right)$, and overall level of stress as compared to one year ago $\left(\mathrm{F}_{1,206}=1.241, \mathrm{P}=.291, \mathrm{ES}=.012, \beta=.268\right)$.

There was no significant difference for gender $\mathrm{x}$ first year or second year graduate assistant for academic $\left(\mathrm{F}_{1,206}=.480, \mathrm{P}=.620, \mathrm{ES}=.005, \beta=.128\right)$, social $\left(\mathrm{F}_{1,206}=.398, \mathrm{P}=\right.$ $.672, \mathrm{ES}=.004, \beta=.114)$, financial concerns $\left(\mathrm{F}_{1,206}=1.104, \mathrm{P}=.334, \mathrm{ES}=.011, \beta=.242\right)$, overall level of stress $\left(\mathrm{F}_{1,206}=1.355, \mathrm{P}=.260, \mathrm{ES}=.013, \beta=.290\right)$, and overall level of stress as compared to one year ago $\left(\mathrm{F}_{1,206}=.651, \mathrm{P}=.523, \mathrm{ES}=.006, \beta=.158\right)$. (Table D25) 


\section{DISCUSSION}

The central purpose of the study was to identify the levels of stress of certified athletic training graduate assistants. The first hypothesis of this study positively indicated that there would be a significant difference in the levels of stress between gender. The results of the study indicated that there were no significant difference between genders for any of the measured stressors. Based on this the hypothesis is rejected.

The second hypothesis of the study stated that there would be a significant difference in the levels of stress between a first year and second year graduate assistant. For this hypothesis, the results indicated no significant difference between a first year and second year graduate assistant. So this hypothesis was also rejected.

Finally the third hypothesis stated that there would be a significant difference in the levels of stress between gender and a first year and second year graduate assistant. The data revealed that the interaction between gender and a first year and a second year graduate assistant did not yield a significant difference. This hypothesis was also rejected.

Gender

Even though the data analyses did not yield any statistically significant differences between gender and levels of stress, the means between gender for the stressors were slightly different. (See Table D21) Of the five main stressors, females reported higher levels of stress than the males. Of these five stresses, overall level of stress had the greatest difference (even though not statistically significant) between gender with females higher than males. This coincides with Stilger et al, ${ }^{12}$ results in that females reported experiencing greater overall stress during the academic year than males. Participants commented that since the season is coming to 
an end, final duties were piling up on top of the normal daily activities and school work. At times their job appeared to be overwhelming. In addition, the overall level of stress this year as compared to last year had some mixed comments expressed by the participants. These include more stress this year than last year, such as finishing their thesis, graduating, and finding employment. Other participants commented that they were better able to deal with the stress this year because of better adaptation to their environment.

Academic or work concerns exhibited a slightly higher mean for females than males. Stilger et $\mathrm{al}^{12}$ reported that over the course of an academic year, undergraduate female athletic training students reported higher overall stress than male athletic training students. On the other hand, Misra and McKean's ${ }^{16}$ study of college students found that although females exhibited better time management skills, there were no significant observed difference in regards to lower academic stress. Some expressed comments from the participants on academic stress in the QSQ were "the graduate program is very stressful because it is not very applicable to athletic training and requires a lot of time; along with the professors having no idea how many hours we work in comparison to their GA student's hours."

Stress in the work place can be viewed in two ways. First, that stress is an individual's problem in which the person's characteristics are the main causes of job stress. ${ }^{28}$ Second, that the job in and of itself is stressful and it is necessary for the company to address that before it gets out of hand. ${ }^{28}$ The employer needs to be understanding of the personal lives of the employee with flexibility in the job to reduce the stress. ${ }^{10}$ Although not having a specific question in this study, work stress can be anything from day to day occurrences to unexpected events at the clinical site. Work stress can be related to the hours worked, responsibilities, and 
working relationship with coaches and supervisors. These situations vary from not agreeing with how things are run, to not getting along with co-workers, or dealing with athletes that are non-compliant. In the Athletic training setting, work stress usually involves overworking. Overworking decreases productivity and increases stress. ${ }^{10}$ Work stress was stated well by one participant. "My athletic training assignment requires me to be here so much it does not leave much time for anything else. In addition it leaves little time to get school work, and administrative work completed because of spending so much time at practice and rehabilitating my athletes."

Social stress means were also slightly higher for females than males. Some subjects from Reed and Giacobbi's ${ }^{13}$ study expressed feelings of having to keep everybody happy as a social stress. However, in this study, social stress was reported to be of little concern for the participants. Even though they expressed "that they had little time to spend with their significant other or to try and make new friends," this wasn't a category that exposed them to high stress levels.

Financial stress means were shown to be higher for females than males. The greatest financial concern for the male and female undergraduate athletic training students were not being able to find a part-time job due to the time spent in the clinical setting. ${ }^{12}$ With graduate assistants, their concern was that the stipend might not be enough to cover living expenses. However, their greatest concern is that the hours spent at the clinical site does not equate to the stipend received. This in itself can be more of a stressor. It was expressed in the study by comments written by the participants that stated " they were not able to pay bills on the stipend and that the amount of the stipend is not enough for what is expected of the graduate assistant." 
When comparing gender and the remaining stressor means from the QSQ, the muscle tension category (muscle tension, headaches, backaches, and/or muscle aches) indicated the greatest difference between males and females. Females reported their muscle tension to be in the moderate category $(5.04 \pm 2.543)$, where as the males were in the little category $(3.87 \pm$ 2.413), as found in Table D23. Forty six and eight tenths percent( $(\mathrm{n}=97)$ of all of the participants rated muscle tension in the moderate category. This was the only physical stressor when comparing gender where the mean was rated in the moderate category. The greatest percentage of responses $(14.5 \%, \mathrm{n}=30)$ in the extreme category was for muscle tension. Muscle tension is an easily distinguishable physical manifestation of stress. As for other noticeable extreme range categories, forgetfulness $(15 \%, \mathrm{n}=30)$ and sleeping disturbances $(10.2 \%, \mathrm{n}=21)$ were also considerably high.

First Year and Second Year Graduate Assistants

Academic stress was ranked higher by the second year graduate assistants than the first years. This is consistent with a study on nurse practitioner students who reported that their current level of stress being in their last year, is the highest it's ever been. ${ }^{22}$ As for the second year graduate assistants, preparing for graduation and finishing their thesis were stressful. Also the second year graduate assistants reported higher financial stress than the first years. This might be related to the debt they accrue for their undergraduate and graduate education, along with the payments on student loans that will begin within six months of graduation.

First year graduate assistants rated social stress, overall level of stress, and overall stress this year to last year higher than the second year graduate assistants. Social stress can be attributed to starting a new job in a new area and not knowing anyone. The adjustment period 
can be very stressful for people who might not be very outgoing. As for overall stress and overall stress this year as compared to last year, this increase of stress for the first year graduate assistants is based on the increase of responsibility in the transition from an undergraduate athletic training student to a certified athletic trainer with more that may entail the supervision of undergraduate athletic training students.

No matter how stress is defined, all definitions have a similar component, indicating that everyone's reaction to a stressor will differ. A stressor is a stimuli that an individual will react to in either a positive or negative manner. Some people respond to stress in a positive manner and use it as a motivation tool. These individuals will take the stress placed upon them and use it to motivate themselves to get better and/or get work completed. Others may react in a negative manner towards stress. For example the individual's reaction to the stress and that stress can manifest itself physically and emotionally. When a person lets the stress affect them in a negative manner, then the stress can manifest itself in physical symptoms like fatigue, irritability, sleeplessness, headaches or migraines, vulnerability to colds and flu, and nervousness. ${ }^{11,34}$ Some psychological symptoms of stress include depression, anxiety or frustration, decreased job satisfaction, and forgetfulness. ${ }^{34}$ From the health index portion of the questionnaire the physical therapy students filled out, neurologic and emotional complaints were most often experienced. ${ }^{30}$ In this study physical and psychological symptoms were either in the little or moderate level, respectively. Thus indicating as with the other stressors reported on earlier, that certified athletic training graduate assistants did not respond to having extreme stress at the time of this study

In this study, the greatest difference for the remaining stressors from the QSQ between a 
first year and second year graduate assistant was on the forgetfulness category $(5.32 \pm 2.359$; $4.58 \pm 2.393$ ), respectively. (See Table D24) Both were in the moderate range but the means for the first years on forgetfulness was higher than the second years. This category was given a higher rank because the participants commented that they had trouble concentrating on their studies, unable to remember details, demonstrated a lack of attention, and were unable to motivate themselves to get work done. These physical manifestations were also demonstrated in Reed and Giacobbi's study. ${ }^{13}$

Coping

The other purpose of the study was to identify the coping responses of the graduate assistants. Some people respond to stress in a positive manner and use it as a motivation tool. These types of people will take the stress placed upon them and use it to motivate themselves to get better and/or get work completed. Others may react in a negative manner towards stress. The results of the study show that the participants have used various forms of active coping, planning, using emotional support, and using humor often. This is positive in that according to Tully's ${ }^{25}$ study, nursing students reported lower levels of distress when they used more problem solving methods of coping. Similarly, first year initial preparation program students in physical therapy, first chose trying to analyze the problem followed by talking the problem over with a friend. ${ }^{21}$ The participants in their study were using constructive means of coping with their stress. Female introductory psychology students in Sigmon et al's ${ }^{35}$ study, were shown to use emotion focused coping more so than males in an academic setting. There were no gender differences in regard to whether problem focused or acceptance coping strategies were being utilized. A participant in this study commented that family is a stress reliever. In Reed and 
Giacobbi's study, all of these coping strategies (active coping, planning, emotional support, and humor) were used with their participants. ${ }^{13}$ One strategy in particular, planning, helped them to keep organized by scheduling out their day, and keeping the tasks at hand so as to eliminate the stress if the task was not completed. ${ }^{13}$ Also the interviewees used emotional support not just to seek emotional comfort, but to take out some of their anger on friends or "snapping at the athletes." ${ }^{13}$ Humor was used to make light of the situation, along with "teasing" their fellow classmates. ${ }^{13}$ Family can also be a stress reliever as was written by one participant in this study.

The participants were not denying the existence of their stress. Over $80 \%$ of the participants chose response \#1 ("I haven't been doing this at all") for the questions that specifically dealt with denial (\#19, \# 20). Not only were the participants not denying the stress but $49.8 \%$ were also not blaming themselves for what is happening (\#28). In fact based on the responses to questions \#7 (65.2\%) and \#8 (69.1\%)the participants were accepting what was happening to them.

The behavioral disengagement category of the BCQ showed that $64.3 \%$ and $70.5 \%$ of the participants were not giving up on dealing with the stress and were not giving up attempting to cope, respectively. These findings are different from the results of Reed and Giacobbi's study. ${ }^{13}$ Their study noted that 3 out of the 6 certified graduate athletic training students fell into the mental or behavioral disengagement category, in which case those participants tried to avoid or totally ignore the situation. ${ }^{13}$ Though they may not be ignoring the stress, self distraction has been used to take their mind off of the stress in this study.

Self distraction method of coping such as leisure activity, was shown to be used, although not all of the time. The responses to these two questions (\#17, \#18) were mostly with 
responses two and three. They might not be not doing leisure activities involving going to movies, watching TV, reading, daydreaming, sleeping, shopping, or other activities to take their mind off things all of the time, but they are using this strategy. Of the participants in this study, $20.6 \%$ reported doing about 10 hours of leisure activities per week. Self distraction can be good if used for a short period of time. However, if it is used as an avoidance of the stress it can be detrimental. In fact if this type of avoidance coping behavior is increased it can lead to an increase in psychological distress. ${ }^{36} \mathrm{~A}$ frequently reported self distraction behavior expressed by the participants was procrastination due to lack of motivation or just plain tired.

A majority of respondents $(66.7 \%$ \& $72.5 \%)$ said that they did not resort to using drugs or alcohol to make themselves feel better or just to help them get through the stress (\#23, \#24). However, some of the participants commented that they have turned to coffee and caffeinated drinks. Our results are similar to a study using nursing students where drugs and alcohol were not used in coping. ${ }^{24}$ Further, coping with wishing things were different, comfort eating, drinking, smoking or taking medications, or taking it out on others was found to have more of an effect on increasing rather than relieving stress levels for the nursing students. ${ }^{25}$

A little less than half (47.8\%) who responded to question \#21, have not been saying things to let their unpleasant feelings escape. However, $39.1 \%$ are expressing their negative feelings to some extent. A few of the participants expressed that they talk to their family about their problems but that they don't want to dump all of their problems onto their family. Others felt that they don't know how to express their problems to the full time staff because they are considered part time staff members or do not want the problem to be interpreted as a sign of weakness. 
Religion has been shown to be a good coping strategy, ${ }^{21,29}$ but this study indicated that $82.6 \%$ have not been trying to find comfort in their religion or spiritual beliefs and have not been praying or meditating, respectively. However, $34.3 \%$ of the respondents were using religion a lot to cope with their stress. This is similar to the results in Reed and Giacobbi's ${ }^{13}$ study in which 33\% (2 out of 6 ) of their participants did say that they were going to church and praying. Mermann's ${ }^{29}$ study of physicians noted that 10 out of the 23 interviewed attended either church or synagogue somewhat regularly. This represents a higher percentage $(43.5 \%)$ that use religion, which is different from the results found in this study. An interesting finding from Francis and Naftel's ${ }^{21}$ study is that the most frequently used coping strategies by the physical therapy assistant students was praying and talking their problems over with their friends and family.

Instrumental support (i.e seeking advice or actual support for the stress) (\#15, \#16) was not shown in this study to be widely used by the participants. The majority of the participants selected response number two. Other studies have shown instrumental or social support to be helpful in decreasing stress. ${ }^{23,36}$ In Reed and Giacobbi's study, 5 of the 6 participants found instrumental social support to be important. ${ }^{13}$ In their study participants were interviewed instead of completing a questionnaire. This may have allowed a more free flowing conversation to take place and allowed for an expression of emotions versus just selecting a number to correspond with their emotions.

More importantly is that, participants selected response number four more often for positive reframing than for the other coping questions. The participants have been trying to see the stress in a different light, to make it more positive and have been looking for something good in what is happening. Participants recognize the stress that they are experiencing and are 
attempting to do something about it. Some participants expressed that their second year was less stressful than their first year, perhaps based on being more adept at dealing with the stress, knowing what is expected from them, and that they have adapted to their environment.

However, a few have expressed that their second year became more stressful because of trying to finish their thesis and looking for employment.

Even though the participants reported having moderate overall levels of stress, day to day hassles, forgetfulness, and muscle tension to name a few, they were engaging in activities to decrease the stress. The highest percentage of the participants were exercising at least 5 hours a week $(14.5 \% \mathrm{n}=28)$, they were using time management to better plan out their days, and were seeking support. All of these activities aid in decreasing stress.

Limitations of the Study

At the time the survey was sent out, the participants may not have been highly stressed as we would have liked for the study. October, December, and March were the most stressful months in regards to academic stress. ${ }^{12}$ Since this study took place during the last week of February and the reminder sent out the first week of March, the participants may not have been under a high level of stress at the time of filling out the questionnaire battery. This could be due to an upcoming spring break or a decrease in the amount of sports to cover in the spring semester. Also few responses to the questionnaire battery were sent with the follow up email in March. For the first year graduate assistant the decrease in stress may have also been due to being better adapted to their surroundings as opposed to their fall semester.

The low response rate of $20.7 \%(n=207)$ could be due to a number of factors. First off the estimated time to take the survey was about 20 to 30 minutes. This may have seemed like 
too much time to complete the survey or that 70 questions may have been just too many to answer at the time they received the email. Secondly, in some of the participants reply's to me, they mentioned they were no longer a graduate assistant. This may have been the case with many of the recipients of the emails in which case they did not change their status with the NATA.

\section{CONCLUSION}

Even though there were no statistical significant results, we did find that females reported higher stress levels than males and that the means were variable for the stress levels between a first year graduate assistant and a second year graduate assistant. The participants in this study were using more positive than negative coping strategies in responding to stress, such as using active coping, planning, positive reframing, acceptance, humor, and emotional support. Overall though the participants did not respond to having extreme stress at the time of this study and were using more positive than negative coping strategies when stress was experienced. 


\section{REFERENCES}

1. Rabin S, Feldman D, Kaplan Z. Stress and intervention strategies in mental health professionals. Brit J Med Psych. 1999;72(2):159-164.

2. Romano JL. Psychoeducational interventions for stress management and well being. $J$ Counseling Development. 1992;71:199-202.

3. Gieck JH. Stress management in athletic training. J Athl Train. 1984;19:115-119.

4. Dewe PJ. Stressor frequency, tension, tiredness and coping: some measurement issues and a comparison across nursing groups. $J$ Adv Nurs. 1989;14:308-320.

5. Hendrix AE, Acevedo EP, Herbert E. An examination of stress and burnout in certified athletic trainers at Division IA universities. J Athl Train. 2000;35:139-144.

6. Westerman BJ, Sullivan PA, Nashman HW. Coping interventions for athletic trainers: curriculum strategies. NATA News. 2004;July:43-47.

7. Capel SA. Psychological and organizational factors related to burnout in athletic trainers. Athl Train J Natl Athl Train Assoc. 1986;57:322-328.

8. Dolan MG. Managing stress and burnout in athletic therapy. Athl Ther Today. 1998;3(3):23.

9. Staurowsky E, Scriber K. An analysis of selected factors that affect the work lives of athletic trainers employed in accredited educational programs. $J$ Athl Train. 1998;33(3):244-248.

10. Gieck J, Brown RS, Shank RH. The burnout syndrome among athletic trainers. J Athl Train. 1982;17(1):36-40.

11. Campbell D, Miller MH, Robinson WW. The prevalence of burnout among athletic trainers. J Athl Train. 1985;20:110-113,148.

12. Stilger VG, Etzel EF, Lantz CD. Life-stress sources and symptoms of collegiate student athletic trainers over the course of an academic year. J Athl Train. 2001;36:401-407.

13. Reed S., Giacobbi PR Jr. The stress and coping responses of certified graduate athletic training students. J Athl Train. 2004;39(2):193-200.

14. Akgun S, Ciarrochi J. Learned resourcefulness moderates the relationship between academic stress and academic performance. Ed Psychol. 2003;23(3):287-294. 
15. Skowron EA, Wester SR, Azen R. Differentiation of self mediates college stress and adjustment. J Couns Devel. 2004;82:69-78.

16. Misra R, McKean M. College students' academic stress and its relation to their anxiety, time management, and leisure satisfaction. Am J Health Sc. 2000;16(1):41-51.

17. Struthers CW, Perry RP, Menec VH. An examination of the relationship among academic stress, coping, motivation, and performance in college. Res Higher Ed. 2000;41(5):581-592.

18. Lumley MA, Provenzano KM. Stress management through written emotional disclosure improves academic performance among college students with physical symptoms. $J E d$ Psych. 2003;95(3):641-650.

19. Ross SE, Niebling BC, Heckert TM. Sources of stress among college students. Coll Stu J. 1999;33(2):312-318.

20. Munley A. Sources of hospice staff stress and how to cope with it. Nurs Clin North Am. 1985;20:343-355.

21. Francis KT, Naftel DC. Perceived sources of stress and coping strategies in allied health students: a model. J Allied Health. 1983;12:262-272.

22. Maville JA, Kranz PL, Tucker BA. Perceived stress reported by nurse practitioner students. J Am Ac Nurs Prac. 2004;16(6):257-262.

23. Lo R. A longitudinal study of perceived level of stress, coping and self-esteem of undergraduate nursing students: an Australian case study. J Adv Nurs. 2002;39(2):119-126.

24. Kirkland ML. Stressors and coping strategies among successful female African American baccalaureate nursing students. J Nursing Ed. 1998;37:5-14.

25. Tully A. Stress, sources of stress and ways of coping among psychiatric nursing students. $J$ Psych Mental Health Nurs. 2004;11:43-47.

26. Stewart SM, Lam TH, Betson CL, Wong CM, Wong AMP. A prospective analysis of stress and academic performance in the first two years of medical school. Med Edu. 1999;33:243250 .

27. Radcliffe $\mathrm{C}$, Lester $\mathrm{H}$. Perceived stress during undergraduate medical training: a qualitative study. Med Edu. 2003;37:32-35.

28. Arthur AR. Work related stress, the blind men and the elephant. British J Guidance Couns. 2004;32:157-170. 
29. Mermann AC. Coping strategies of selected physicians. Perspect Biol Med. 1990;33:268279.

30. O'Meara S, Kostas T, Markland F, Previty JC. Perceived academic stress in physical therapy students. J Phys Ther Ed. 1994;8(2):71-75.

31. Frazer GH, Echternach JL. Response of physical therapy students to stress indicators. $J$ Phys Ther Ed. 1991;5(2):72-77.

32. Otani A. Psychometric Studies of the Campus Stress Questionnaire (CSQ): A Maximum Likelihood Factor Composite Technique [dissertation]. Morgantown, WV: West Virginia Univeristy; 1985.

33. Carver CS. You want to measure coping but your protocol's too long: consider the Brief COPE. Intern J Behavioral Med. 1997;4(1):92-100.

34. Keegan L. Alternative and complementary modalities for managing stress and anxiety. Critical Care Nurs. 2003;23(3):55-58.

35. Sigmon ST, Stanton AL, Snyder CR. Gender differences in coping: a further test of socialization and role constraint theories. Sex Roles. 1995;33:565-587.

36. Tyler P, Cushway D. Stress in nurses: the effects of coping and social support. Stress Med. 1995;11:243-251. 
APPENDICES 


\section{APPENDIX A}

\section{THE PROBLEM}

Research Question

A certified athletic training graduate assistant is typically someone who has just graduated from their respective undergraduate program and has passed the NATA-BOC exam. This individual will continue to attend school to obtain their master's degree while making the transition from athletic training student to entry level certified athletic trainer which entails more responsibility. Due to this, the graduate assistant is under an above normal amount of stress. These stresses might include academic, social, financial, and general life stresses. ${ }^{3,13}$

Athletic trainers do tend to exhibit high stress levels but with regard to burnout they are lower as compared to other allied health professionals. ${ }^{7}$ Preventing burnout should be addressed in the beginning of an athletic trainers' career by understanding the stress levels involved, especially if that person decides to become a graduate assistant. The stress levels of graduate

athletic trainers, has been an overlooked area of study. Previous studies ${ }^{3,5,7,8,10,11}$ noted stress and burnout in full time certified athletic trainer's but only one study ${ }^{13}$ explored stress in graduate athletic training students. Reed and Giacobbi ${ }^{13}$ identified the sources of stress and the coping responses of six certified graduate athletic training students. Six sources of stress were identified as athletic training duties, comparing job duties, responsibilities as a student, time management, social evaluation, and future concerns. However, only six subjects were used in the study. In order to understand stress levels in certified graduate athletic training students, more studies need to be completed. The research question was what were the overall stress levels of certified athletic training graduate assistants at the time of questionnaire distribution? 
Experimental Hypotheses

1. There will be a significant difference in the levels of stress between gender.

2. There will be a significant difference in the levels of stress between a first year and second year graduate assistant.

3. There will be a significant difference in the levels of stress between gender and a first year and second year graduate assistant.

\section{Assumptions}

1. Subjects did answer the questionnaire openly, honestly and to the best of their ability.

2. Subjects were experiencing stress at the time the questionnaire was answered.

3. The quick stress questionnaire is valid and reliable for the population being studied.

Delimitations

1. Only certified athletic trainers participated in the study.

2. Only graduate assistants that are in a non-tenure, part time athletic training position participated in the study.

3. The study may only able to be generalized to other graduate students with an assistantship in athletic training.

\section{Operational Definitions}

1. Academic Stress - Refers to anything dealing with credit hours, class work load, professors, and grades.

2. Burnout - "A chronic condition that develops when one is working too hard for too long in a high-pressure situation."

3. Certified Athletic Trainer (ATC) - "Are unique health care providers who specialize in prevention, assessment, treatment and rehabilitation of injuries and illness that occur to athletes and the physically active." NATA

4. Certified Student - "A membership category in the NATA that is open to individuals possessing current NATA-BOC certification who are enrolled as full-time graduate $\underset{\substack{\text { students } \\ \text { Byaws }}}{\text { working toward an advanced degree at an accredited college or university."NATA }}$ 
5. Coping - "An individual's constantly changing cognitive and behavioral efforts to manage external and internal demands or conflicts." 37

6. Financial Stress - This can include stress about the stipend and cost of living associated with the graduate assistantship.

7. Graduate Assistant - A qualified individual who is obtaining a master's degree while working in their specialized field and being compensated with a stipend.

8. Life Stress - Can include anything that might typically happen throughout the course of a lifetime. "For example death of a spouse, divorce, marriage, pregnancy, sexual difficulties, death of a close family member, change in residence, etc." ${ }^{3}$

9. NATA - National Athletic Trainer's Association.

10. NATA-BOC - "Certification program for entry-level athletic trainers and re-certification standards for certified athletic trainers. Additionally, the BOC has established the continuing education requirements that a certified athletic trainer must satisfy in order to maintain current status as a BOC certified athletic trainer." bocatcorg

11. Quick Stress Questionnaire - "Is a 25-item, self report inventory designed to measure sources of stress and stress-related symptoms in college students along a 9-point Likert scale $(1=\text { little stress, } 9 \text { = extreme stress })^{\text {"12 }}$

12. Stress - "Is the individual's physical and emotional reaction to demands placed on him."

${ }^{3}$ This can include academic, financial, social, and life stress.

13. Stressor - Is a stimuli that an individual will than react to in either a positive or negative manner.

14. Social Stress - Interaction between fellow students, friends, coaches, and professors can cause stress.

15. Work Stress - Entails the amount of hours worked, responsibilities, and working relationship with coaches and supervisors.

\section{Limitations}

The limitations in this study are some threats to internal and external validity.

1. History - an internal validity threat based on the possibility of external events affecting the response of participants. 
2. Maturation - an internal validity threat based on the possibility of psychological processes, external to the research, that could also affect participant responses.

3. Testing - an internal validity threat based on reactive measurement tools such as rating scales which may change the event which the researcher is attempting to measure.

4. Selection of participants - an external validity threat based on the choice of participants as a random group or an experimentally accessible group.

5. Generalization of findings to other settings - an external validity threat where the findings of the participants are generalized towards a target population.

Significance of the Study

Athletic trainers tend to overextend themselves in order for all of the sports to be provided coverage. Continuing to overextend themselves can increase their stress levels. There are other stressful situations such as social, academic, financial, and general life stresses that can add to already increasing stress levels related to work. Management and prevention of stress is not always the easiest thing to accomplish. There are limited studies that specifically observed the stress levels of certified athletic training graduate assistants and ways to reduce the stress outside of suggesting coping skills. The significance of the study lies in the understanding of the level of stress that the graduate assistants are experiencing, so that academic programs and clinical sites can change their hours and/or academic load to reduce the overall stress levels. 


\section{APPENDIX B}

\section{LITERATURE REVIEW}

Introduction

Stress can affect anyone in any profession and chronic stress can lead to burnout. ${ }^{5}$ Compared to other allied health professionals, athletic training has a lower burnout rate. ${ }^{7}$ Of the studies that exist, most have focused on full time certified athletic trainers. ${ }^{3,5-11}$ Results from those studies indicated that stress levels exist, and were either lower than other professions, ${ }^{7}$ or if lower levels of hardiness and social support and higher levels of athletic training issues were evident, higher levels of stress were experienced. ${ }^{5}$ On the other hand, little research has been conducted on stress levels for undergraduate ${ }^{12}$ and graduate athletic training students. ${ }^{13}$ It can be hypothesized that since both groups of students are preparing to advance in the profession and both are exposed to the same type and levels of stress similar to full time certified athletic trainers, that the results from these studies would be similar. Although graduate athletic training students are exposed to supervision and additional responsibilities not experienced by undergraduate students, the studies indicated that stress levels are more similar to other college students, ${ }^{14-19}$ or students in nursing, ${ }^{1,4,20-25}$ medicine, ${ }^{1,26-29}$ and physical therapy fields. ${ }^{30-31}$ Stilger et al. ${ }^{12}$ noted that stress levels fluctuated throughout the course of an academic calendar with academic and financial concerns to be the highest stressors. With that, the certified athletic training graduate students may experience more stress related to supervision and responsibility. Reed and Giacobbi ${ }^{13}$ determined six dimensions of stress and then evaluated coping responses suggesting that graduate students be encouraged to use problem-focused and emotion-focused forms of stress coping strategies. In this literature review stress, sources of stress, burnout, 
stresses in allied health professions (nursing, medical, physical therapy, athletic training), and coping strategies will be discussed.

Stress

Stress is an interesting occurrence that affects everyone. The definition is never absolute and has been defined differently in many studies. Rabin ${ }^{1}$ described stress as a condition in which there is a marked perceived discrepancy between demands on an individual and the individual's ability to respond. Additionally stress can be described as the interaction between stressors and the individual as well as how the individual reacts to the stressors. ${ }^{2}$ Another way of describing stress, as described by Munley, ${ }^{20}$ is to divide it into two categories including those relating to the inner experience or personal characteristics of care-givers and those located in the work environment. Gieck ${ }^{3}$ describes stress as the individual's physical and emotional reaction to demands placed on him. Whereas, Dewe ${ }^{4}$ suggests that stress is what arises from those situations in which the individual perceives are about to tax his/her physical or emotional resources.

No matter how stress is defined, all definitions have a similar component, indicating that everyone's reaction to a stressor will differ. A stressor is a stimuli that an individual will react to in either a positive or negative manner. Some people respond to stress in a positive manner and use it as a motivation tool. These types of people will take the stress placed upon them and use it to motivate themselves to get better and/or get work completed. Others may react in a negative manner towards stress. For example the individual's reaction to the stress and that stress can manifest itself physically and emotionally. When a person lets the stress affect them in a negative manner, then the stress can manifest itself in physical symptoms like fatigue, 
irritability, sleeplessness, headaches or migraines, vulnerability to colds and flu, and

nervousness. ${ }^{11,34}$ Some psychological symptoms of stress include depression, anxiety or frustration, decreased job satisfaction, and forgetfulness. ${ }^{34}$

Sources of Stress

Individuals experience stress resulting from academic, financial, life concerns, social, and work. Academic stress are stressors involved with credit hours, class work load, professors, and grades. Stress has been shown to impair academic functioning in two ways. ${ }^{18}$ First by interfering with adaptive behaviors noted in studying or class attendance. ${ }^{18}$ Second by impeding vital cognitive processes such as attention and concentration. ${ }^{18}$ Some sources include studying and taking exams. ${ }^{16}$

Financial stress can vary because not everyone is in the same financial situation. Bills and general living expenses can include rent, food, utilities, transportation, clothing, and entertainment. Undergraduate athletic training students may have more financial stress than typical college students because of the unpaid clinical hours, which then doesn't leave time for a part time job. ${ }^{12}$

Life stress is anything that might typically happen throughout the course of a lifetime. "Examples of life stress include death of a spouse, divorce, marriage, pregnancy, sexual difficulties, death of a close family member, and a change in residence." ${ }^{3}$ This can obviously happen at any point in time in the course of our lives. In addition, life stress can also include limited opportunity for career advancement, poor working conditions, job dissatisfaction, and conflicts with co-workers. ${ }^{12}$ Westerman ${ }^{6}$ added personal stressors that include time away from family, lack of respect, pressure to heal athletes, meddling non-medical personnel, and juggling 
responsibilities. Day to day stressors include lack of administrative support, poor relationship with coaches or administrators, inadequate financial compensation, lack of advancement opportunities, and family and social issues. ${ }^{8}$

Social stress can be considered interaction between fellow students, friends, coaches, and professors. For example, having a roommate that you don't get along with can cause considerable amounts of stress. Another way of describing social stress is as themes of being labeled as a student, self-presentation, and pleasing others. ${ }^{13}$ Some subjects from Reed \& Giacobbi's ${ }^{13}$ study expressed feelings of having to keep everybody happy as a social stress.

Work stress can be anything that involves the work place. Such as the amount of hours worked, responsibilities, and working relationship with coaches and supervisors. These can vary from not agreeing with how things are run, to not getting along with co-workers, or dealing with athletes that are non-compliant. Stress in the work place can be viewed in two ways. First, that stress is an individual's problem in which the person's characteristics are the main causes of job stress. ${ }^{28}$ Second, that the job in and of itself is stressful and it is necessary for the company to address that before it gets out of hand. ${ }^{28}$ The employer needs to be understanding of the personal lives of the employee with flexibility in the job to reduce the stress. ${ }^{10}$ Overworking decreases productivity and increases stress. ${ }^{10}$

Burnout

"One can experience stress without burnout, but not burnout without stress." ${ }^{96}$ Burnout is a reaction to chronic stress that involves negative interactions between environmental and personal characteristics, and as a chronic condition that develops when one is working too hard for too long in a high-pressure situation. ${ }^{5}$ Maslach and Jackson ${ }^{38}$ go further to describe burnout 
as a syndrome. "The burnout syndrome is a set of symptoms leading to a debilitating psychological condition commonly associated with chronic stress and is a syndrome comprising emotional exhaustion, depersonalization and reduced personal accomplishment." ${ }^{38}$ No matter how burnout is described, it is important to understand the stress levels associated with your profession to try and prevent the severe condition of burnout.

A study by $\mathrm{Capel}^{7}$ examined 332 full time and part time certified athletic trainers from 13 states including Alaska, Arizona, California, Colorado, Hawaii, Idaho, Montana, Nevada, New Mexico, Oregon, Utah, Washington, and Wyoming. Subjects were administered the Athletic Trainers Questionnaire which consists of four parts, with one part being the Maslach Burnout Inventory. Based on the results from the Maslach Burnout Inventory, none of the studied certified athletic trainers showed high levels of burnout. ${ }^{7}$ This indicates that average burnout scores for certified athletic trainers are lower than other helping professions. ${ }^{7}$

In contrast, the study done by Hendrix et $a 1,{ }^{5}$ which also used the Maslach Burnout Inventory, found that individuals who reported lower levels of hardiness and social support and higher levels of athletic training issues experienced higher levels of stress appraisal. In addition a significant relationship was noted with perceived stress being a predictor of emotional stress. ${ }^{5}$ The athletic trainers studied scored slightly higher in regards to personal accomplishment, which demonstrates personal satisfaction with their work. ${ }^{5}$

Campbell et $\mathrm{al}^{11}$ looked at the prevalence of burnout among athletic trainers from 221 usable questionnaires from the NATA Clinical Symposium in June of 1984. From the returned questionnaires, the Athletic Training Burnout Scales was developed. The results from the study identified five characteristics that the burned out athletic trainer exhibited. A burned out athletic 
trainer is male, is slightly younger than the athletic trainer who is not burned out, tends to not have children, is a head athletic trainer, and is more likely to work with other athletic trainers. ${ }^{11}$ Another interesting finding of the study was that there tended to be more burned out athletic trainers from the NATA districts six (Arkansas and Texas) and seven (Arizona, Colorado, New Mexico, Utah, and Wyoming). ${ }^{11}$ Also burnout does not discriminate in that regardless of education, work background, and demographic makeup burnout can happen to anyone. ${ }^{11}$

Burnout can manifest itself with physical symptoms. These symptoms include a general lack of energy, physical and cognitive symptoms of stress, negativism, emotional withdrawal, and a reduced sense of accomplishment. ${ }^{39}$ Dedication and commitment eventually leads to overdedication and over commitment. ${ }^{10}$ This then in addition leads to psychological symptoms like anxiety and depression, sleeplessness, and the inability to handle stress. ${ }^{10}$ Overall fatigue is the most common symptom. ${ }^{10}$ Recovering from severe burnout can take anywhere from several months to years to overcome. ${ }^{39}$

Stresses in Allied Health Professions

General college students, physical therapy students, nursing students, medical students, certified athletic trainers, undergraduate athletic training students, and graduate assistant athletic trainers are just some of the professions in allied health that will be discussed. All allied health professions have in common a dual training schedule. This means that there is academic as well as clinical experience to these professions. Students go to classes in the morning and then their clinical experience in the afternoon. Academic work load and clinical work load can vary by semester. General college students are being included here because graduate assistants and undergraduate athletic training students are considered college students. 
General college students: Students are exposed to stressors that are unique to being in school. Many studies have been completed on college students and their stress. ${ }^{14-19,40}$ Some of those stressors include challenging course loads, university bureaucracies, problems in managing one's time, and personal finances. ${ }^{15}$ Academic stress does significantly affect academic performance. ${ }^{14}$ In one study Akgun ${ }^{14}$ submitted two questionnaires (self-control schedules and undergraduate stress questionnaire) to first year undergraduate students from which 141 responded. Their results did not find a significant relationship between stress, resourcefulness, and gender. ${ }^{14}$ However, the results did reveal that the GPA was impacted by students who scored low in resourcefulness. ${ }^{14}$ Misra and McKean ${ }^{16}$ administered four self-report questionnaires that addressed academic stress, leisure satisfaction, time management, and trait and state anxiety. Of the 249 full time undergraduate students that responded, lower levels of stress were found when the student felt in control of the situation. ${ }^{16}$ There was also lower academic stress when a student exhibited better time management skills rather than participating in leisure satisfaction activities. ${ }^{16}$ In some cases academic stress is inversely related to their course grade. ${ }^{17}$ This has implications of interfering with the students studying, class attendance, attention and concentration. ${ }^{18}$ These studies however did not take into consideration the students major or their financial status.

Physical therapy students: Financial stress can be ranked high among sources of stress but for 77 University of Alabama in Birmingham physical therapy students it was not one of the highest. ${ }^{21}$ The students were given a personal sources of stress questionnaire that was designed to identify potential sources of stress. ${ }^{21}$ Academics and research were the highest sources of stress, with financial second. ${ }^{21}$ In this particular setting these student do undergo a combination 
of academic and clinical education at the same time. According to O'Meara et $\mathrm{al}^{30}$ students ranked studying the wrong material followed by studying for examinations as a high stress. This study sent questionnaires that included an academic stress scale, the health index, and a demographic data sheet to 254 students from four New England colleges. ${ }^{30}$ From the health index portion of the questionnaire the physical therapy students filled out, neurologic and emotional complaints were most often experienced. ${ }^{30}$ This study suggests that the reason the emotional stress was expressed on the questionnaire was due to the part that the intensity of their schedules limit time for other activities like family, friends, and relaxation. ${ }^{30}$ In a similar study by Frazer and Echternach, ${ }^{31}$ instead of studying the wrong material as being the most stressful, this study found that taking notes ranked highest. These were 113 students at two universities that completed the questionnaire that included the academic stress scale, the student stress scale, and the freedom from compulsion scale. ${ }^{31}$ The results of the questionnaire revealed that these students experienced stress, expressed high health risks due to the stress, and had a tendency to be moderately or severely obsessive-compulsive. ${ }^{31}$

Nursing students: "Nursing has one of the highest rates of suicide, psychiatric outpatient referrals, and the lowest life expectancy of any of the professions." 36 Obviously nurses are under a considerable amount of stress, which may be why many studies were completed on the stress levels of nursing students. One such study done by Maville et $\mathrm{al}^{22}$ used students in their final year of a university based nurse practitioner program. The purpose of the study was to observe how the nurse practitioner students perceived stress. Twelve students were interviewed. ${ }^{22}$ Results indicated that the students in their last year reported their current stress to be above average and the highest it's ever been. ${ }^{22}$ Some of their sources of stress are a result of returning 
to school in which case their financial support has significantly decreased but responsibilities remained the same along with the increase of demands placed on them. ${ }^{22}$ A similar study was completed using undergraduate nursing students. A questionnaire was administered to first year, second year, and third year nursing students at Southern Cross University in Lismore, New South Wales, Australia. They found that the major sources of stress were academic, financial, family, and health. ${ }^{23}$ An interesting finding was that a good number of the students lived close to poverty level. ${ }^{23}$ Similarly a study by Tully ${ }^{25}$ who gave questionnaires involving a general health, student nurse stress index and ways of coping to 35 psychiatric nursing students found that the students scores on the tests indicate that they are at risk at developing a physical or psychiatric illness due to the stress. The main stressors were academic and financial. ${ }^{25}$

Medical students: Similar to nursing students, medical students have had to deal with pain, suffering, anxiety, and death on a daily basis, which can lead to stress. ${ }^{29}$ Stress can impinge on decision making and reduce students' abilities to establish good relationships with patients. ${ }^{41}$ This can inevitably lead to their lack of confidence in themselves and being unsatisfied with their clinical practice. ${ }^{41}$ Saipanish ${ }^{41}$ found that third year medical students were under more stress than medical students in other academic years. The stress levels could be attributed to any number of things. One thing that is certain is allied health professionals go through academic and clinical experiences at possibly the same time, which can be stressful for anyone. Stewart et a ${ }^{26}$ study surveyed 121 first year medical students twice, once before classes and then again eight months later. The examiners also obtained the students pre-medical academic scores and then their grades from the first two years of medical school. ${ }^{26}$ They used this information to see if pre-medical school scores would predict their medical school scores 
along with the related stress involved. The results indicated that with stress, students who's grades were weaker before medical school reported more stress than those with better grades. ${ }^{26}$ Pressure of work and transition periods were sited to be stressful for 21 final year medical students at the University of Birmingham. ${ }^{27}$ The transition period includes going from a preclinical science student to an apprentice student on the ward. ${ }^{27}$

Certified Athletic Trainers: Numerous studies have been done on the stress levels of full time certified athletic trainers. ${ }^{3,5-8,10,11}$ Staurowsky and Scriber ${ }^{9}$ in 1998, designed a survey of athletic trainer workloads, criteria for retention and promotion, and salary levels. Their results indicated that an average week is working over 50 hours and possibly teaching classes aside from having to supervise athletic training students. ${ }^{9}$ This finding on the amount of hours worked is different than sited in Gieck's ${ }^{3}$ study from 1984. Gieck's ${ }^{3}$ study mentioned that a certified athletic trainer can typically work a $65-80$ hour work week. This variability could be due to an increase in staffing and rules on the amount of staff needed for appropriate care. Hendrix et $\mathrm{al}^{5}$ study administered a questionnaire that included the hardiness test, the social support questionnaire, the athletic training survey, the perceived stress scale, and the Maslach Burnout Inventory. Results indicated that from the perceived stress scale, emotional exhaustion was consistently reported. ${ }^{5}$ Athletic training issues survey reported high stress was reported when they could relate to more of the issues in the survey. ${ }^{5}$ Some of these issues include not having time to myself, budget limitations, and personality conflicts. ${ }^{5}$

In 1982 Gieck et al ${ }^{10}$ examined the burnout syndrome in certified athletic trainers. The case studies presented contributing factors to burnout. For example being overworked, unable to relax, no time away from work, and being fatigued. ${ }^{10}$ This along with taking care of the 
physically active and administrative duties can be stressful, especially if there is a lack of cooperation. The amount of hours put into the job and the low pay scale cause some frustration. Sometimes entry-level positions with a "low salary but good experience" doesn't help with reducing stress. ${ }^{3}$ This study offered insights into what stress certified athletic trainers are under and some ways to cope.

Athletic training students and graduate assistants: Both undergraduate athletic training students and graduate athletic training assistants are similar in that both are attending school and gaining clinical experience. However, there are some differences. Undergraduate athletic training students clinical hours are more closely monitored than graduate assistants. Graduate assistants have a more advanced course load to take and are working as certified athletic trainers as part of their assistantship. In similarity, both are under represented in the literature in regard to studies about stress levels.

Both are representative of a typical college student in regard to academic stress. However, the financial stress can vary for each. For example graduate assistants make just enough money to live, but they are working what is equivalent to full time hours for part time pay. Although the graduate assistant may not be compensated enough, there is sometimes a tuition waver included with the stipend to cover academic expenses. Athletic training students financial stress can manifest itself in a way that is different from a typical college student in that the undergraduate athletic training student is devoting part-time job hours as clinical experience but are not being paid and then don't have the time for a part time job to offset costs. ${ }^{12}$ There were 20 undergraduate athletic training students that were administered the Quick Stress Questionnaire at eight equal time periods throughout an academic year. ${ }^{12}$ The results are 
concurrent with other studies in that academics is a major source of stress and that time management can alleviate stress. ${ }^{12}$

Reed and Giacobbi ${ }^{13}$ interviewed six certified graduate athletic training students to gather their sources of stress and coping responses throughout the course of an academic year. The sources of stress gathered consisted of athletic training duties, comparing job duties, responsibilities as a student, time management, social evaluation and future concerns. ${ }^{13}$ Athletic training duties "includes supervisory role, injury care or prevention, documentation, and communicating with others."13 For comparing job duties, this dimension was described as comparing their graduate assistantship job duties with that of the other staff certified athletic trainers. Graduate assistants and general college students have expressed stress with regards to responsibilities as a student, time management, and future concerns. Social evaluation was described as "demonstrating ability, being labeled as a student, self-presentation, and pleasing others." 13

Coping strategies

Strategies to reduce stress are unique to each individual, but there are general principles anyone can follow to cope with stress or to prevent excess stress. Two hundred forty nine full time undergraduate college students were studied by Misra and McKean. ${ }^{16}$ They found time management behaviors and feeling in control of the situation reduced academic stress.

Lumley $^{18}$, administered a questionnaire to an Introduction to Psychology class. Of the 74 college students in the study their grades improved after writing about the stress of adjusting to college. ${ }^{18}$ It is important to note that the improvement in grades was not due to a decrease in credit hours or taking less difficult classes. ${ }^{18}$ In comparison, Struthers et al ${ }^{17}$ observed the stress of 203 
college students in an Introduction to Psychology class and found that the students stress and course grade were comparable to their academic coping style and motivation.

Basic coping strategies like active problem-solving or planning, talking to friends or engaging in other activities, and exercise can benefit anyone in any profession. ${ }^{36}$ In allied health professions, not all professions cope in the same way. Dewe ${ }^{4}$ found that charge nurses used problem-oriented strategies more than staff and enrolled nurses, while emotion-focused strategies was used more by enrolled nurses, and passive strategies was used more by staff nurses. One thousand eight hundred one questionnaires were administered to nurses working in general and obstetric hospitals throughout 29 hospital boards in New Zealand. ${ }^{4}$ Passive strategies is described as smoking more, drinking more coffee and taking a day off. ${ }^{4}$

In athletic training Reed and Giacobbi's, ${ }^{13}$ observed general coping responses of six interviewed graduate athletic training students. Six dimensions of coping were developed from the results of the interviews. These general dimensions include planning, instrumental social support, adjusting to job responsibilities, positive evaluations, emotional social support, humor, wishful thinking, religion, mental or behavioral disengagement, activities outside the profession, and other outcomes. ${ }^{13}$ Each of these dimensions then had subgroups. Planning further included scheduling, time management, organization, and delegation. Instrumental social support includes seek advice and conversation. Adjusting to job responsibilities was seeking information and adapting. Positive evaluation was being able to view the whole picture and acceptance. Mental and behavioral disengagement is being able to ignore the situation and avoidance of the situation. Activities outside of the profession include exercise and recreational activities. The authors advocated that a combination of planning, adjusting to job 
responsibilities, positive evaluations, activities outside the profession, and social support will help in decreasing stress. ${ }^{13}$

Summary

In summary, stress can affect anyone in any profession and chronic stress can lead to burnout. Stress can be described as the interaction between stressors and the individual along with how the individual reacts to the stressors. Stress can result from academic, financial, life, social, and work aspects of life. The burnout syndrome is a set of symptoms leading to a debilitating psychological condition commonly associated with chronic stress and is a syndrome comprising emotional exhaustion, depersonalization and reduced personal accomplishment. Physical symptoms of burnout include a general lack of energy, physical and cognitive symptoms of stress, negativism, emotional withdrawal, and a reduced sense of accomplishment. As with the allied health profession students of nursing, medicine, and athletic training all have dual schedules of academic and clinical experiences that can cause excessive stress. To deal with this excessive stress a combination of planning, adjusting to job responsibilities, positive evaluations, activities outside the profession, and social support will help in decreasing stress. 


\section{APPENDIX C}

\section{ADDITIONAL METHODS}

Table C1: Initial Email to Recipients

February 18, 2005

Dear Graduate Assistant,

This message is a request for you to complete a questionnaire for a graduate athletic training student at West Virginia University. The three purposes of this study are to: a) identify the levels of stress of certified athletic training graduate assistants; b) identify the amount of stress as a result of the length of the graduate assistant position or gender; and c) provide suggestions on how to manage stress and decrease the chance of burnout. This thesis is being completed to partially fulfill requirements for the completion of a Master of Science Degree in Athletic Training.

The following questionnaire includes 17 demographics questions, 27 multiple choice on the Likert scale from 1 to 9 , and 28 multiple choice on a scale from 0 to 3 . The questionnaire should take approximately 30 minutes to complete. Please go to the following website to take the questionnaire: http://www.wvu.edu/ physed/AT_stress_survey/

Your involvement in this survey will be kept anonymous and confidential. I will not ask you to provide your name with this survey, and will not present any information that could allow for individual participants to be identified. The website will direct you to the consent form. Reading and submitting the consent form will serve as your consent to participate in the study.

I hope that you will participate in this questionnaire, as it could be very beneficial for the graduate assistants in their understanding of the stress involved and in the prevention of burnout. Thank you very much for your time. Should you have any questions about this letter or the questionnaire, please feel free to contact Darya Feldman, ATC at (304)598-9358 or dfeldma1@mix.wvu.edu,or Dr. Michelle A. Sandrey at (304)293-3295 ext 5220 or msandrey@mail.wvu.edu

Thank you very much for your participation in this project.

Password:

Sincerely,

Darya Feldman, ATC 
March 2, 2005

Dear Graduate Assistant,

I am a West Virginia University graduate athletic training student and I am conducting research on the stress levels of graduate assistants. The three purposes of this study are to: a) identify the levels of stress of certified athletic training graduate assistants; b) identify the amount of stress as a result of the length of the graduate assistant position or gender; and c) provide suggestions on how to manage stress and decrease the chance of burnout. This research is being conducted to partially fulfill requirements for the completion of the Master of Science Degree in Athletic Training.

The following questionnaire includes 17 demographics questions, 27 multiple choice on the Likert scale from 1 to 9 , and 28 multiple choice on a scale from 0 to 3 . The questionnaire should take approximately 30 minutes to complete. Please go to the following website to take the questionnaire:

http://www.wvu.edu/ physed/AT_stress_survey/

I will be the only person who will have access to the information provided. Your responses will remain anonymous and confidential. Participation in this questionnaire is completely voluntary and you are not required to answer every question. You have the right to withdraw any data you submit at any time. Completing and submitting this questionnaire will serve as your consent to participate. If you choose to participate, please complete the questionnaire and submit it.

If you have any questions or concerns, please feel free to contact me by phone at (304)598-9358 or via e-mail at dfeldma1@mix.wvu.edu. You may also contact my supervisor, at (304)293-3295 x 5220 or msandrey@mail.wvu.edu with any questions regarding this research. This is a follow up letter to let you know there is still time to fill out the questionnaire. If you have already filled out the questionnaire thank you as this is just a reminder email.

Thank you in advance for you participation.

Password:

Sincerely,

$\underline{\text { Darya Feldman, ATC }}$ 


\section{CONSENT AND INFORMATION FORM}

\section{LEVELS OF STRESS AND COPING IN CERTIFIED ATHLETIC TRAINING GRADUATE ASSISTANTS}

\section{Introduction}

I have been asked to participate in this research study, which has been explained to me by an email from Darya Feldman, ATC. This research is being conducted by Darya Feldman, ATC, and Michelle A, Sandrey, Ph.D., ATC in the School of Physical Education at West Virginia University.

\section{Purpose of the Study}

The purposes of this study is to identify the levels of stress of certified athletic training graduate assistants, the amount of stress as a result of the length of the graduate assistant position and gender, and to provide suggestions on how to manage stress and decrease the chance of burnout.

\section{Description of Procedure}

This study involves completing a survey once in the month of February that will ask me questions about stress, burnout, and coping related to my graduate assistantship and academic courses. The enclosed questionnaire consists of a 25 item Quick Stress Questionnaire (QSQ), 28 item Brief COPE questionnaire, and 17 demographic questions. The QSQ uses a nine-point Likert scale ranging from 1 (little stress) to 9 (extreme stress) to measure sources of stress and stress related symptoms. The Brief COPE uses a four point scale ranging from 0 (I haven't been doing this at all) to 3 (I've been doing this a lot). The survey will take approximately 30 minutes to complete. I understand that I do not have to answer all of the questions if I do decide to participate. After two weeks, I will be sent a follow-up e-mail that will remind me to complete the questionnaire and/or to thank me for participating. A randomized individual password will be provided to you in the initial and followup email. The website will ask for the password when submitting the survey. Your email address has been obtained through the National Athletic Trainers Association.

Submission Date

$\overline{\text { Initials }} \quad \overline{\text { Date }}$ 


\section{LEVELS OF STRESS AND COPING IN CERTIFIED ATHLETIC TRAINING GRADUATE ASSISTANTS}

\section{Risks and Discomforts}

There are no known risks from participation in this study, except for the mild frustration and introspection that might be associated with the completion of a survey about stress and burnout.

\section{Alternative}

I understand that I do not have to participate in this study, and that I can stop my participation in this study at any time.

\section{Benefits}

This questionnaire will benefit graduate assistants in providing suggestions on how to manage stress and decrease the chance of burnout.

\section{Contact Persons}

For more information about this research, I can contact Darya Feldman, ATC at (304)598-9358 or dfeldma1@mix.wvu.edu, or Dr. Michelle A. Sandrey at (304)293-3295 ext 5220 or msandrey@mail.wvu.edu. For information regarding my rights as a research subject, I may contact the Executive Secretary of the Institutional Review Board of West Virginia University at (304)293-7073.

\section{Confidentiality}

I understand that any information about me obtained as a result of my participation in this research will be kept as confidential as legally possible. I understand that the confidentiality of information transmitted over the Internet cannot be guaranteed. In any publications that result from this research, neither my name nor any information from which I might be identified will be published without my consent. The researchers will collect the students' e-mail address from the National Athletic Trainers Association. The addresses will be saved in an e-mail file of the researcher for distribution purposes. The students will be given a password, which will be used to determine how many times the student participated and to determine their stress levels over time. These e-mail addresses and passwords will be deleted upon completion of the study. 


\section{LEVELS OF STRESS AND COPING IN CERTIFIED ATHLETIC TRAINING GRADUATE ASSISTANTS}

\section{Voluntary Participation}

Participation in this study is voluntary. I understand that I am free to withdraw my consent to participate in this study at any time. Refusal to participate or withdrawal will involve no penalty or loss of benefits. I have been given opportunity to ask questions about the research, and I have received answers concerning areas I did not understand.

By clicking the URL address in the letter sent via e-mail and entering my password, I am consenting to participate in this study in which I will fill out the questionnaire and return by clicking the submit button.

If I do not wish to participate in the study, I can decline simply by deleting the e-mail. 
Personal Data

Credentials

1. What certifications do you have?

-NATABOC

$-\mathrm{CSCS}$

-Other

-No response

Academic

2. Are you in a one or a two-year graduate program?

-One-year program

-Two-year program

-No response

3. Do you receive a tuition waiver?

-Partial

-Full

-None

-No response

4. Are you required to do a research project/thesis?

-Yes

$-\mathrm{No}$

-No response

5. How many credit hours do you have this semester?

6. How would you rate your course load this semester?

-Heavy

-Moderate

-Light

-No response

Clinical

7. What is your athletic training assignment?

-HS

-College

-Clinic

-None

-Other

-No response
8. How many hours does your contract require you to be at your assignment per week?

9. Approximately how much time do you spend at your assignment per week?

10. About how long does it take you to travel to your assignment? (one-way)

11. How many sports are you required to cover at your assignment?

12. Do you have any assistants, If yes, how many?

13. If you receive a stipend, how much do you receive?

$-0-2999$

$-3000-5999$

$-6000-8999$

$-9000-11999$

$-12000+$

-Not applicable

-No response

14. If you receive a stipend, how often will you receive it?

-Monthly

-Each semester

-Yearly

-Other

-Not applicable

-No response

Activity

15. Approximately how many hours per week do you spend exercising?

16. Approximately how many hours per week do you spend studying?

17. Approximately how many hours per week do you spend doing leisure activities? 
WVU/CPSC Quick Stress Questionnaire

No portion of the Quick Stress Questionnaire may be reproduced without the consent of The WVU Counseling \& Psychological Services Center

Student Services Center

West Virginia University

Morgantown WV 26506

1. Sex:

- Male

- Female

- No response
2. Class Rank:

- First year graduate

- Advanced graduate

- No response

For the purpose of this questionnaire, stress is defined as the total combination of life pressures, demands, hassles, frustrations, disappointments, environmentally and self-imposed tasks and deadlines that you perceive, react to, and feel. Select the number that represents your stress level and briefly explain it in the comment field below the areas that you feel are most stressful for you.

3. Academic or work concerns:

- 1 (Little)

- 2

- 3

- 4

- 5 (Moderate)

- 6

- 7

- 8

- 9 (Extreme)

- No response

Comments

4. Social/Personal Relationships:

- 1 (Little)

- 2

- 3

- 4

- 5 (Moderate)

- 6

- 7

- 8

- 9 (Extreme)

- No response
Comments

5. Family Concerns:

- 1 (Little)

- 2

- 3

- 4

- 5 (Moderate)

- 6

- 7

- 8

- 9 (Extreme)

- No response

Comments

6. Financial Concerns:

- 1 (Little)

- 2

- 3

- 4

- 5 (Moderate)

- 6

- 7

- 8 
- 9 (Extreme)

- No response

Comments

7. Self-Image:

- 1 (Little)

- 2

- 3

- 4

- 5 (Moderate)

- 6

- 7

- 8

- 9 (Extreme)

- No response

Comments

8. Health Concerns:

- 1 (Little)

- 2

- 3

- 4

- 5 (Moderate)

- 6

- 7

- 8

- 9 (Extreme)

- No response

Comments

9. Sexual Concerns:

- 1 (Little)

- 2

- 3

- 4

- 5 (Moderate)

- 6

- 7

- 8

- 9 (Extreme)

- No response

Comments

10. Day-to-Day Hassles:

- 1 (Little)

- 2

- 3

- 4
- 5 (Moderate)

- 6

- 7

- 8

- 9 (Extreme)

- No response

Comments

11. Other:

- 1 (Little)

- 2

- 3

- 4

- 5 (Moderate)

- 6

- 7

- 8

- 9 (Extreme)

- No response

Comments

People react to stress in various ways. How do you react? (Rate on the scales below.) Please rate all scales by blackening the number that best represents your own reaction(s). Also, for each list of reactions, enter the ones that are most typical or troubling for you in the comment field.

12. Feelings of depression, hopelessness, powerlessness, and/or poor self-esteem - 1 (Little)

- 2

- 3

- 4

- 5 (Moderate)

- 6

- 7

- 8

- 9 (Extreme)

- No response

Comments

13. Anger, hostility, irritability, and/or resentment

- 1 (Little)

- 2

- 3

- 4 
- 5 (Moderate)

- 6

- 7

- 8

- 9 (Extreme)

- No response

Comments

14. Apprehension, fears, and/or worrying

- 1 (Little)

- 2

- 3

- 4

- 5 (Moderate)

- 6

- 7

- 8

- 9 (Extreme)

- No response

Comments

15. Muscle tension, headaches, backaches, and/or muscle aches

- 1 (Little)

- 2

- 3

- 4

- 5 (Moderate)

- 6

- 7

- 8

- 9 (Extreme)

- No response

Comments

16. Indigestion, stomachache, diarrhea, ulcer attacks, constipation, and/or colitus

- 1 (Little)

- 2

- 3

- 4

- 5 (Moderate)

- 6

- 7

- 8

- 9 (Extreme)

- No response

Comments
17. Tics, tremors, and/or muscle spasms

- 1 (Little)

- 2

- 3

- 4

- 5 (Moderate)

- 6

- 7

- 8

- 9 (Extreme)

- No response

Comments

18. Sleeping disturbances, insomnia, oversleeping, night awakening, and/or troublesome dreams

- 1 (Little)

- 2

- 3

- 4

- 5 (Moderate)

- 6

- 7

- 8

- 9 (Extreme)

- No response

Comments

19. Eating disorders, overeating, and/or undereating

- 1 (Little)

- 2

- 3

- 4

- 5 (Moderate)

- 6

- 7

- 8

- 9 (Extreme)

- No response

Comments

20. Excessive drinking and/or use of drugs (including nicotine and caffeine)

- 1 (Little)

- 2

- 3

- 4 
- 5 (Moderate)

- 6

- 7

- 8

- 9 (Extreme)

- No response

Comments

21. Forgetfulness, mental inefficiency, inability to study, and/or lack of motivation

- 1 (Little)

- 2

- 3

- 4

- 5 (Moderate)

- 6

- 7

- 8

- 9 (Extreme)

- No response

Comments

22. Hypertension (high blood pressure)

- 1 (Little)

- 2

- 3

- 4

- 5 (Moderate)

- 6

- 7

- 8

- 9 (Extreme)

- No response

Comments

23. Acne, eczema, hives, breaking out, and/or skin blotching and skin blanching

- 1 (Little)

- 2

- 3

- 4

- 5 (Moderate)

- 6

- 7

- 8

- 9 (Extreme)

- No response

Comments
24. Avoidance behavior (e.g. procrastination, escapism, TV watching, excessive partying, class cutting, absenteeism)

- 1 (Little)

- 2

- 3

- 4

- 5 (Moderate)

- 6

- 7

- 8

- 9 (Extreme)

- No response

Comments

25. Overall level of stress and anxiety at this time

- 1 (Little)

- 2

- 3

- 4

- 5 (Moderate)

- 6

- 7

- 8

- 9 (Extreme)

- No response

Comments

26. Overall stressors (studies, jobs, etc.) this year in comparison to those of last year

- 1 (Little)

- 2

- 3

- 4

- 5 (Moderate)

- 6

- 7

- 8

- 9 (Extreme)

- No response

Comments 
27. Your level of stress when you first sought counseling or treatment (ignore if not applicable)

- 1 (Little)

- 2

- 3

- 4

- 5 (Moderate)

- 6

- 7

- 8

- 9 (Extreme)

- No response

Comments 
Select the number that corresponds to how you've been coping with your stress as it relates to the given situation.

1. I've been concentrating my efforts on doing something about the situation I'm in.

- 1 - I haven't been doing this at all

- 2

- 3

- 4 - I've been doing this a lot

- No response

2. I've been taking action to try to make the situation better.

- 1 - I haven't been doing this at all

- 2

- 3

- 4 - I've been doing this a lot

- No response

3. I've been trying to come up with a strategy about what to do.

- 1 - I haven't been doing this at all

- 2

- 3

- 4 - I've been doing this a lot

- No response

4. I've been thinking hard about what steps to take.

- 1 - I haven't been doing this at all

- 2

- 3

- 4 - I've been doing this a lot

- No response

5. I've been trying to see it in a different light, to make it seem more positive.

- 1 - I haven't been doing this at all

- 2

- 3

- 4 - I've been doing this a lot

- No response

6. I've been looking for something good in what is happening.

- 1 - I haven't been doing this at all
- 2

- 3

- 4 - I've been doing this a lot

- No response

7. I've been accepting the reality of the fact that it has happened.

- 1 - I haven't been doing this at all

- 2

- 3

- 4 - I've been doing this a lot

- No response

8. I've been learning to live with it.

- 1 - I haven't been doing this at all

- 2

- 3

- 4 - I've been doing this a lot

- No response

9. I've been making jokes about it.

- 1 - I haven't been doing this at all

- 2

- 3

- 4 - I've been doing this a lot

- No response

10. I've been making fun of the situation.

- 1 - I haven't been doing this at all

- 2

- 3

- 4 - I've been doing this a lot

- No response

11. I've been trying to find comfort in my religion or spiritual beliefs.

- 1 - I haven't been doing this at all

- 2

- 3

- 4 - I've been doing this a lot

- No response 
12. I've been praying or meditating.

- 1 - I haven't been doing this at all

- 2

- 3

- 4 - I've been doing this a lot

- No response

13. I've been getting emotional support from others.

- 1 - I haven't been doing this at all

- 2

- 3

- 4 - I've been doing this a lot

- No response

14. I've been getting comfort and understanding from someone.

- 1 - I haven't been doing this at all

- 2

- 3

- 4 - I've been doing this a lot

- No response

15. I've been trying to get advice or help from other people about what to do.

- 1 - I haven't been doing this at all

- 2

- 3

- 4 - I've been doing this a lot

- No response

16. I've been getting help and advice from other people.

- 1 - I haven't been doing this at all

- 2

- 3

- 4 - I've been doing this a lot

- No response

17. I've been turning to work or other activities to take my mind off things.

- 1 - I haven't been doing this at all

- 2

- 3

- 4 - I've been doing this a lot

- No response
18. I've been doing something to think about it less, such as going to movies, watching TV, reading, daydreaming, sleeping, or shopping.

- 1 - I haven't been doing this at all

- 2

- 3

- 4 - I've been doing this a lot

- No response

19. I've been saying to myself "this isn't real."

- 1 - I haven't been doing this at all

- 2

- 3

- 4 - I've been doing this a lot

- No response

20. I've been refusing to believe that it has happened.

- 1 - I haven't been doing this at all

- 2

- 3

- 4 - I've been doing this a lot

- No response

21. I've been saying things to let my unpleasant feelings escape.

- 1 - I haven't been doing this at all

- 2

- 3

- 4 - I've been doing this a lot

- No response

22. I've been expressing my negative feelings.

- 1 - I haven't been doing this at all

- 2

- 3

- 4 - I've been doing this a lot

- No response

23. I've been using alcohol or other drugs to make myself feel better.

- 1 - I haven't been doing this at all

- 2

- 3

- 4 - I've been doing this a lot

- No response 
24. I've been using alcohol or other drugs to help me get through it.

- 1 - I haven't been doing this at all

- 2

- 3

- 4 - I've been doing this a lot

- No response

25. I've been giving up trying to deal with it.

- 1 - I haven't been doing this at all

- 2

- 3

- 4 - I've been doing this a lot

- No response

26. I've been giving up the attempt to cope.

- 1 - I haven't been doing this at all

- 2

- 3

- 4 - I've been doing this a lot

- No response

27. I've been criticizing myself.

- 1 - I haven't been doing this at all

- 2

- 3

- 4 - I've been doing this a lot

- No response

28. I've been blaming myself for things that happened.

- 1 - I haven't been doing this at all

- 2

- 3

- 4 - I've been doing this a lot

- No response 


\section{APPENDIX D}

\section{ADDITIONAL RESULTS}

Table D1. Demographic Information descriptive statistics for credit hours

\begin{tabular}{clcc}
\hline Credit Hours & Percentage $(\mathrm{n})$ & Credit Hours & Percentage $(\mathrm{n})$ \\
\hline .00 & $1 \%(\mathrm{n}=2)$ & 10.00 & $6 \%(\mathrm{n}=12)$ \\
.50 & $.5 \%(\mathrm{n}=1)$ & 11.00 & $3.5 \%(\mathrm{n}=7)$ \\
1.00 & $.5 \%(\mathrm{n}=1)$ & 12.00 & $8 \%(\mathrm{n}=16)$ \\
3.00 & $3 \%(\mathrm{n}=6)$ & 13.00 & $2 \%(\mathrm{n}=4)$ \\
4.00 & $.5 \%(\mathrm{n}=1)$ & 14.00 & $.5 \%(\mathrm{n}=1)$ \\
5.00 & $.5 \%(\mathrm{n}=1)$ & 15.00 & $3.5 \%(\mathrm{n}=7)$ \\
6.00 & $22.9 \%(\mathrm{n}=46)$ & 16.00 & $2 \%(\mathrm{n}=4)$ \\
7.00 & $2 \%(\mathrm{n}=4)$ & 17.00 & $.5 \%(\mathrm{n}=1)$ \\
8.00 & $1.5 \%(\mathrm{n}=3)$ & 19.00 & $.5 \%(\mathrm{n}=1)$ \\
9.00 & $40.8 \%(\mathrm{n}=82)$ & 25.00 & $.5 \%(\mathrm{n}=1)$ \\
\hline
\end{tabular}

Table D2. Demographic Information descriptive statistics for athletic training assignment

Assignment

High School

College

Clinic

None

Other

No Response
Percentage (n)

$26.6 \%(\mathrm{n}=55)$

$60.9 \%(\mathrm{n}=126)$

$3.9 \%(\mathrm{n}=8)$

$2.4 \%(\mathrm{n}=5)$

$4.8 \%(\mathrm{n}=10)$

$1.4 \%(\mathrm{n}=3)$ 
Table D3. Demographic Information descriptive statistics for contract hours per week.

\begin{tabular}{cccl}
\hline Contract hrs & Percentage $(\mathrm{n})$ & Contract hrs & Percentage $(\mathrm{n})$ \\
\hline .00 & $3.9 \%(\mathrm{n}=7)$ & 18.50 & $.6 \%(\mathrm{n}=1)$ \\
3.00 & $.6 \%(\mathrm{n}=1)$ & 20.00 & $58.1 \%(\mathrm{n}=104)$ \\
4.00 & $.6 \%(\mathrm{n}=1)$ & 21.00 & $.6 \%(\mathrm{n}=1)$ \\
9.00 & $.6 \%(\mathrm{n}=1)$ & 22.50 & $2.2 \%(\mathrm{n}=4)$ \\
10.00 & $.6 \%(\mathrm{n}=1)$ & 24.00 & $1.1 \%(\mathrm{n}=2)$ \\
12.00 & $1.1 \%(\mathrm{n}=2)$ & 25.00 & $8.4 \%(\mathrm{n}=15)$ \\
13.00 & $.6 \%(\mathrm{n}=1)$ & 27.50 & $.6 \%(\mathrm{n}=1)$ \\
13.50 & $.6 \%(\mathrm{n}=1)$ & 28.00 & $.6 \%(\mathrm{n}=1)$ \\
14.00 & $.6 \%(\mathrm{n}=1)$ & 30.00 & $4.5 \%(\mathrm{n}=8)$ \\
15.00 & $2.8 \%(\mathrm{n}=5)$ & 35.00 & $2.2 \%(\mathrm{n}=4)$ \\
17.00 & $.6 \%(\mathrm{n}=1)$ & 40.00 & $6.7 \%(\mathrm{n}=12)$ \\
17.50 & $.6 \%(\mathrm{n}=1)$ & 50.00 & $.6 \%(\mathrm{n}=1)$ \\
18.00 & $.6 \%(\mathrm{n}=1)$ & 65.00 & $.6 \%(\mathrm{n}=1)$ \\
\hline
\end{tabular}

Table D4. Demographic Information descriptive statistics for actual hours worked per week.

\begin{tabular}{cccc}
\hline Worked hrs & Percentage $(\mathrm{n})$ & Worked hrs & Percentage $(\mathrm{n})$ \\
\hline .00 & $.5 \%(\mathrm{n}=1)$ & 33.00 & $.5 \%(\mathrm{n}=1)$ \\
8.00 & $.5 \%(\mathrm{n}=1)$ & 34.00 & $1 \%(\mathrm{n}=2)$ \\
9.00 & $.5 \%(\mathrm{n}=1)$ & 35.00 & $13.8 \%(\mathrm{n}=28)$ \\
12.00 & $1.5 \%(\mathrm{n}=3)$ & 36.00 & $.5 \%(\mathrm{n}=1)$ \\
15.00 & $.5 \%(\mathrm{n}=1)$ & 37.50 & $.5 \%(\mathrm{n}=1)$ \\
17.50 & $.5 \%(\mathrm{n}=1)$ & 40.00 & $18.2 \%(\mathrm{n}=37)$ \\
20.00 & $5.9 \%(\mathrm{n}=12)$ & 42.00 & $.5 \%(\mathrm{n}=1)$ \\
21.50 & $.5 \%(\mathrm{n}=1)$ & 45.00 & $3.4 \%(\mathrm{n}=7)$ \\
22.00 & $.5 \%(\mathrm{n}=1)$ & 47.50 & $.5 \%(\mathrm{n}=1)$ \\
22.50 & $1.5 \%(\mathrm{n}=3)$ & 50.00 & $7.4 \%(\mathrm{n}=15)$ \\
24.00 & $.5 \%(\mathrm{n}=1)$ & 52.00 & $.5 \%(\mathrm{n}=1)$ \\
25.00 & $3.9 \%(\mathrm{n}=8)$ & 55.00 & $5.4 \%(\mathrm{n}=11)$ \\
27.50 & $3 \%(\mathrm{n}=6)$ & 60.00 & $3.9 \%(\mathrm{n}=8)$ \\
30.00 & $17.2 \%(\mathrm{n}=35)$ & 65.00 & $3.4 \%(\mathrm{n}=7)$ \\
32.00 & $.5 \%(\mathrm{n}=1)$ & 70.00 & $1.5 \%(\mathrm{n}=3)$ \\
32.50 & $.5 \%(\mathrm{n}=1)$ & 75.00 & $1 \%(\mathrm{n}=2)$ \\
\hline
\end{tabular}


Table D5. Demographic Information descriptive statistics for travel time (min).

\begin{tabular}{clcl}
\hline Travel Time & Percentage $(\mathrm{n})$ & Travel Time & Percentage $(\mathrm{n})$ \\
\hline .00 & $2.6 \%(\mathrm{n}=5)$ & 15.00 & $12.8 \%(\mathrm{n}=25)$ \\
1.00 & $.5 \%(\mathrm{n}=1)$ & 20.00 & $8.2 \%(\mathrm{n}=16)$ \\
2.00 & $4.1 \%(\mathrm{n}=8)$ & 25.00 & $1.5 \%(\mathrm{n}=3)$ \\
3.00 & $.5 \%(\mathrm{n}=1)$ & 30.00 & $6.7 \%(\mathrm{n}=13)$ \\
5.00 & $27.7 \%(\mathrm{n}=54)$ & 35.00 & $1.5 \%(\mathrm{n}=3)$ \\
7.00 & $1.5 \%(\mathrm{n}=3)$ & 40.00 & $1.5 \%(\mathrm{n}=3)$ \\
8.00 & $1.0 \%(\mathrm{n}=2)$ & 45.00 & $2.1 \%(\mathrm{n}=4)$ \\
10.00 & $23.6 \%(\mathrm{n}=46)$ & 60.00 & $3.1 \%(\mathrm{n}=6)$ \\
12.50 & $1.0 \%(\mathrm{n}=2)$ & & \\
\hline
\end{tabular}

Table D6. Demographic Information descriptive statistics for number of sports to cover.

\begin{tabular}{cccc}
\hline \# of Sports & Percentage $(\mathrm{n})$ & \# of Sports & Percentage $(\mathrm{n})$ \\
\hline .00 & $3.4 \%(\mathrm{n}=6)$ & 11.00 & $1.1 \%(\mathrm{n}=2)$ \\
1.00 & $24.7 \%(\mathrm{n}=44)$ & 12.00 & $1.1 \%(\mathrm{n}=2)$ \\
1.50 & $.6 \%(\mathrm{n}=1)$ & 13.00 & $3.4 \%(\mathrm{n}=6)$ \\
2.00 & $27.5 \%(\mathrm{n}=49)$ & 14.00 & $1.1 \%(\mathrm{n}=2)$ \\
3.00 & $14.0 \%(\mathrm{n}=25)$ & 15.00 & $3.4 \%(\mathrm{n}=6)$ \\
4.00 & $3.9 \%(\mathrm{n}=7)$ & 16.00 & $.6 \%(\mathrm{n}=1)$ \\
5.00 & $1.7 \%(\mathrm{n}=3)$ & 17.00 & $1.1 \%(\mathrm{n}=2)$ \\
6.00 & $.6 \%(\mathrm{n}=1)$ & 19.00 & $.6 \%(\mathrm{n}=1)$ \\
7.00 & $1.7 \%(\mathrm{n}=3)$ & 21.00 & $.6 \%(\mathrm{n}=1)$ \\
8.00 & $1.1 \%(\mathrm{n}=2)$ & 30.00 & $.6 \%(\mathrm{n}=1)$ \\
9.00 & $1.1 \%(\mathrm{n}=2)$ & 32.00 & $.6 \%(\mathrm{n}=1)$ \\
10.00 & $4.5 \%(\mathrm{n}=8)$ & 38.00 & $1.1 \%(\mathrm{n}=2)$ \\
\hline
\end{tabular}

Table D7. Demographic Information descriptive statistics for number of assistants.

\begin{tabular}{clcl} 
\# of Assistants & Percentage $(\mathrm{n})$ & \# of Assistants & Percentage $(\mathrm{n})$ \\
\hline .00 & $47.3 \%(\mathrm{n}=78)$ & 5.00 & $1.8 \%(\mathrm{n}=3)$ \\
1.00 & $18.8 \%(\mathrm{n}=31)$ & 6.00 & $1.2 \%(\mathrm{n}=2)$ \\
1.50 & $.6 \%(\mathrm{n}=1)$ & 7.00 & $1.8 \%(\mathrm{n}=3)$ \\
2.00 & $14.5 \%(\mathrm{n}=24)$ & 8.00 & $.6 \%(\mathrm{n}=1)$ \\
3.00 & $8.5 \%(\mathrm{n}=14)$ & 9.00 & $1.2 \%(\mathrm{n}=2)$ \\
4.00 & $3.6 \%(\mathrm{n}=6)$ & & \\
\hline
\end{tabular}


Table D8. Demographic Information descriptive statistics for the participants stipend

\begin{tabular}{ll}
\hline Stipend & Percentage $(\mathrm{n})$ \\
\hline$\$ 0-2999$ & $10.1 \%(\mathrm{n}=21)$ \\
$3000-5999$ & $15 \%(\mathrm{n}=31)$ \\
$6000-8999$ & $30.4 \%(\mathrm{n}=63)$ \\
$9000-11999$ & $28 \%(\mathrm{n}=58)$ \\
$12000+$ & $13 \%(\mathrm{n}=27)$ \\
Not applicable & $1 \%(\mathrm{n}=2)$ \\
No response & $2.4 \%(\mathrm{n}=5)$ \\
\hline
\end{tabular}

Table D9. Demographic Information descriptive statistics for how the stipend was received

Received Stipend

Monthly

Each semester

Yearly

Other

Not applicable

No Response
Percentage (n)

$61.8 \%(\mathrm{n}=128)$

$6.3 \%(\mathrm{n}=13)$

$4.8 \%(\mathrm{n}=10)$

$23.2 \%(n=48)$

$1 \%(\mathrm{n}=2)$

$2.9 \%(n=6)$

Table D10. Demographic Information descriptive statistics for hours per week of exercise.

\begin{tabular}{clcc}
\hline Hrs of Exercise & Percentage $(\mathrm{n})$ & Hrs of Exercise & Percentage $(\mathrm{n})$ \\
\hline .00 & $6.2 \%(\mathrm{n}=12)$ & 6.50 & $1.6 \%(\mathrm{n}=3)$ \\
1.00 & $5.2 \%(\mathrm{n}=10)$ & 7.00 & $7.3 \%(\mathrm{n}=14)$ \\
1.50 & $1.6 \%(\mathrm{n}=3)$ & 7.50 & $1.0 \%(\mathrm{n}=2)$ \\
2.00 & $12.4 \%(\mathrm{n}=24)$ & 8.00 & $2.1 \%(\mathrm{n}=4)$ \\
2.50 & $3.1 \%(\mathrm{n}=6)$ & 8.50 & $.5 \%(\mathrm{n}=1)$ \\
3.00 & $12.4 \%(\mathrm{n}=24)$ & 9.00 & $2.6 \%(\mathrm{n}=5)$ \\
4.00 & $9.3 \%(\mathrm{n}=18)$ & 9.50 & $.5 \%(\mathrm{n}=1)$ \\
4.50 & $.5 \%(\mathrm{n}=1)$ & 10.00 & $4.7 \%(\mathrm{n}=9)$ \\
5.00 & $14.5 \%(\mathrm{n}=28)$ & 12.00 & $1.6 \%(\mathrm{n}=3)$ \\
5.50 & $.5 \%(\mathrm{n}=1)$ & 14.00 & $.5 \%(\mathrm{n}=1)$ \\
6.00 & $9.3 \%(\mathrm{n}=18)$ & 15.00 & $2.6 \%(\mathrm{n}=5)$ \\
\hline
\end{tabular}


Table D11. Demographic Information descriptive statistics for hours spent studying per week.

\begin{tabular}{cccl}
\hline Hrs Studying & Percentage $(\mathrm{n})$ & Hrs Studying & Percentage $(\mathrm{n})$ \\
\hline .00 & $1.0 \%(\mathrm{n}=2)$ & 12.00 & $2.5 \%(\mathrm{n}=5)$ \\
.50 & $.5 \%(\mathrm{n}=1)$ & 12.50 & $.5 \%(\mathrm{n}=1)$ \\
1.00 & $2.5 \%(\mathrm{n}=5)$ & 14.00 & $1.0 \%(\mathrm{n}=2)$ \\
1.50 & $.5 \%(\mathrm{n}=1)$ & 15.00 & $8.4 \%(\mathrm{n}=17)$ \\
2.00 & $8.4 \%(\mathrm{n}=17)$ & 16.00 & $.5 \%(\mathrm{n}=1)$ \\
2.50 & $1.5 \%(\mathrm{n}=3)$ & 18.00 & $.5 \%(\mathrm{n}=1)$ \\
3.00 & $5.9 \%(\mathrm{n}=12)$ & 20.00 & $4.0 \%(\mathrm{n}=8)$ \\
4.00 & $6.9 \%(\mathrm{n}=14)$ & 21.00 & $.5 \%(\mathrm{n}=1)$ \\
5.00 & $10.9 \%(\mathrm{n}=22)$ & 25.00 & $3.0 \%(\mathrm{n}=6)$ \\
6.00 & $4.5 \%(\mathrm{n}=9)$ & 30.00 & $.5 \%(\mathrm{n}=1)$ \\
7.00 & $5.0 \%(\mathrm{n}=10)$ & 32.00 & $.5 \%(\mathrm{n}=1)$ \\
7.50 & $2.0 \%(\mathrm{n}=4)$ & 35.00 & $.5 \%(\mathrm{n}=1)$ \\
8.00 & $7.9 \%(\mathrm{n}=16)$ & 36.00 & $.5 \%(\mathrm{n}=1)$ \\
9.00 & $1.5 \%(\mathrm{n}=3)$ & 37.50 & $.5 \%(\mathrm{n}=1)$ \\
10.00 & $16.8 \%(\mathrm{n}=34)$ & 40.00 & $.5 \%(\mathrm{n}=1)$ \\
11.00 & $.5 \%(\mathrm{n}=1)$ & & \\
\hline
\end{tabular}

Table D12. Demographic Information descriptive statistics for hours per week spent doing leisure activities.

\begin{tabular}{clcl}
\hline Hrs of Leisure & Percentage $(\mathrm{n})$ & Hrs of Leisure & Percentage $(\mathrm{n})$ \\
\hline .00 & $2.0 \%(\mathrm{n}=4)$ & 8.00 & $5.5 \%(\mathrm{n}=11)$ \\
.50 & $.5 \%(\mathrm{n}=1)$ & 9.00 & $1.5 \%(\mathrm{n}=3)$ \\
1.00 & $3.5 \%(\mathrm{n}=7)$ & 10.00 & $20.6 \%(\mathrm{n}=41)$ \\
2.00 & $8.0 \%(\mathrm{n}=16)$ & 11.00 & $1.0 \%(\mathrm{n}=2)$ \\
3.00 & $7.5 \%(\mathrm{n}=15)$ & 12.00 & $3.0 \%(\mathrm{n}=6)$ \\
3.50 & $.5 \%(\mathrm{n}=1)$ & 12.50 & $.5 \%(\mathrm{n}=1)$ \\
4.00 & $7.0 \%(\mathrm{n}=14)$ & 15.00 & $8.0 \%(\mathrm{n}=16)$ \\
4.50 & $1.0 \%(\mathrm{n}=2)$ & 16.00 & $.5 \%(\mathrm{n}=1)$ \\
5.00 & $15.6 \%(\mathrm{n}=31)$ & 20.00 & $3.5 \%(\mathrm{n}=7)$ \\
5.50 & $.5 \%(\mathrm{n}=1)$ & 21.00 & $.5 \%(\mathrm{n}=1)$ \\
6.00 & $4.0 \%(\mathrm{n}=8)$ & 30.00 & $1.5 \%(\mathrm{n}=3)$ \\
7.00 & $2.5 \%(\mathrm{n}=5)$ & 36.00 & $.5 \%(\mathrm{n}=1)$ \\
7.50 & $.5 \%(\mathrm{n}=1)$ & & \\
\hline
\end{tabular}


Table D13. Descriptive Statistics for Quick Stress Questionnaire Responses (5 main stresses)

\begin{tabular}{llcc}
\hline Stress & Little $(1-3)$ & Moderate $(4-7)$ & Extreme (8-9) \\
\hline Academic (or work) concerns & $9.2 \%(\mathrm{n}=19)$ & $70.6 \%(\mathrm{n}=146)$ & $20.3 \%(\mathrm{n}=42)$ \\
Social/Personal Relationships & $33.3 \%(\mathrm{n}=69)$ & $61.8 \%(\mathrm{n}=128)$ & $3.8 \%(\mathrm{n}=8)$ \\
Financial Concerns & $13 \%(\mathrm{n}=27)$ & $58.4 \%(\mathrm{n}=121)$ & $28.1 \%(\mathrm{n}=58)$ \\
$\begin{array}{c}\text { Overall level of stress at this time } \\
\text { Overall level of stress this year } \\
\quad\end{array}$ & $23.1 \%(\mathrm{n}=48)$ & $64.8 \%(\mathrm{n}=134)$ & $11.6 \%(\mathrm{n}=24)$ \\
\multicolumn{1}{c}{ to last year } & $18.4 \%(\mathrm{n}=38)$ & $65.7 \%(\mathrm{n}=136)$ & $15 \%(\mathrm{n}=31)$ \\
\hline
\end{tabular}

Table D14. Descriptive Statistics for Quick Stress Questionnaire Responses (remaining stresses)

\begin{tabular}{lllc}
\hline Stress & Little $(1-3)$ & Moderate $(4-7)$ & Extreme (8-9) \\
\hline Family concerns & $43.5 \%(\mathrm{n}=90)$ & $52.7 \%(\mathrm{n}=109)$ & $3.9 \%(\mathrm{n}=8)$ \\
Self-image & $37.7 \%(\mathrm{n}=78)$ & $56.6 \%(\mathrm{n}=117)$ & $5.8 \%(\mathrm{n}=12)$ \\
Health concerns & $48.8 \%(\mathrm{n}=101)$ & $44.9 \%(\mathrm{n}=93)$ & $5.8 \%(\mathrm{n}=12)$ \\
Sexual concerns & $61.8 \%(\mathrm{n}=128)$ & $34.8 \%(\mathrm{n}=72)$ & $2 \%(\mathrm{n}=4)$ \\
Day to Day Hassles & $26.6 \%(\mathrm{n}=55)$ & $64.3 \%(\mathrm{n}=133)$ & $9.2 \%(\mathrm{n}=19)$ \\
Feelings of depression & $54.1 \%(\mathrm{n}=112)$ & $36.7 \%(\mathrm{n}=76)$ & $8.2 \%(\mathrm{n}=17)$ \\
Anger, hostility & $35.8 \%(\mathrm{n}=74)$ & $60.3 \%(\mathrm{n}=125)$ & $2.9 \%(\mathrm{n}=6)$ \\
Apprehension, fears & $34.8 \%(\mathrm{n}=72)$ & $55.6 \%(\mathrm{n}=115)$ & $8.7 \%(\mathrm{n}=18)$ \\
Muscle tension, headaches & $37.2 \%(\mathrm{n}=77)$ & $46.8 \%(\mathrm{n}=97)$ & $14.5 \%(\mathrm{n}=30)$ \\
Indigestion, stomachache & $67.6 \%(\mathrm{n}=140)$ & $23.6 \%(\mathrm{n}=49)$ & $3.8 \%(\mathrm{n}=8)$ \\
Tics, tremors, muscle spasms & $81.1 \%(\mathrm{n}=168)$ & $8.3 \%(\mathrm{n}=17)$ & $1.4 \%(\mathrm{n}=3)$ \\
Sleeping disturbances, insomnia & $43.5 \%(\mathrm{n}=90)$ & $43.1 \%(\mathrm{n}=89)$ & $10.2 \%(\mathrm{n}=21)$ \\
Disordered eating & $57.5 \%(\mathrm{n}=119)$ & $32.4 \%(\mathrm{n}=67)$ & $3.9 \%(\mathrm{n}=8)$ \\
Excessive drinking and/or drug use & $59.4 \%(\mathrm{n}=123)$ & $28.9 \%(\mathrm{n}=60)$ & $5.8 \%(\mathrm{n}=12)$ \\
Forgetfulness, mental inefficiency & $32.9 \%(\mathrm{n}=68)$ & $51.2 \%(\mathrm{n}=106)$ & $15 \%(\mathrm{n}=31)$ \\
Hypertension & $77.8 \%(\mathrm{n}=161)$ & $10.5 \%(\mathrm{n}=22)$ & $0 \%(\mathrm{n}=0)$ \\
Acne, eczema, hives & $69.6 \%(\mathrm{n}=144)$ & $18.4 \%(\mathrm{n}=38)$ & $5.3 \%(\mathrm{n}=11)$ \\
Avoidance behavior & $36.7 \%(\mathrm{n}=76)$ & $51.6 \%(\mathrm{n}=107)$ & $9.6 \%(\mathrm{n}=20)$ \\
\hline
\end{tabular}




\section{Table D15. Brief COPE Questionnaire Results}

\begin{tabular}{|c|c|c|c|c|c|}
\hline Questions & 1 & 2 & 3 & 4 & 5 \\
\hline $\begin{array}{l}\text { 1. I've been concentrating my efforts on doing something } \\
\text { about the situation I'm in }\end{array}$ & $\begin{array}{l}17.9 \% \\
(n=37)\end{array}$ & $\begin{array}{l}28.5 \% \\
(n=59)\end{array}$ & $\begin{array}{l}31.9 \% \\
(n=66)\end{array}$ & $\begin{array}{l}17.9 \% \\
(n=37)\end{array}$ & $\begin{array}{l}3.9 \% \\
(\mathrm{n}=8)\end{array}$ \\
\hline $\begin{array}{l}2 . \text { I've been taking action to try to make the situation } \\
\text { better }\end{array}$ & $\begin{array}{l}10.6 \% \\
(n=22)\end{array}$ & $\begin{array}{l}33.8 \% \\
(n=70)\end{array}$ & $\begin{array}{l}35.3 \% \\
(n=73)\end{array}$ & $\begin{array}{l}16.9 \% \\
(n=35)\end{array}$ & $\begin{array}{l}3.4 \% \\
(n=7)\end{array}$ \\
\hline $\begin{array}{l}\text { 3. I've been trying to come up with a strategy about what } \\
\text { to do }\end{array}$ & $\begin{array}{l}10.1 \% \\
(n=21)\end{array}$ & $\begin{array}{l}31.4 \% \\
(n=65)\end{array}$ & $\begin{array}{l}34.3 \% \\
(n=71)\end{array}$ & $\begin{array}{l}18.8 \% \\
(n=39)\end{array}$ & $\begin{array}{l}5.3 \% \\
(\mathrm{n}=11)\end{array}$ \\
\hline 4. I've been thinking hard about what steps to take & $\begin{array}{l}15.5 \% \\
(n=32)\end{array}$ & $\begin{array}{l}29.5 \% \\
(n=61)\end{array}$ & $\begin{array}{l}28.5 \% \\
(n=59)\end{array}$ & $\begin{array}{l}21.3 \% \\
(n=44)\end{array}$ & $\begin{array}{l}5.3 \% \\
(\mathrm{n}=11)\end{array}$ \\
\hline $\begin{array}{l}\text { 5. I've been trying to see it in a different light, to make it } \\
\text { seem more positive }\end{array}$ & $\begin{array}{l}11.6 \% \\
(n=24)\end{array}$ & $\begin{array}{l}28 \% \\
(n=58)\end{array}$ & $\begin{array}{l}28 \% \\
(n=58)\end{array}$ & $\begin{array}{l}30 \% \\
(n=62)\end{array}$ & $\begin{array}{l}2.4 \% \\
(n=5)\end{array}$ \\
\hline $\begin{array}{l}\text { 6. I've been looking for something good in what is } \\
\text { happening }\end{array}$ & $\begin{array}{l}4.8 \% \\
(n=10)\end{array}$ & $\begin{array}{l}21.7 \% \\
(n=45)\end{array}$ & $\begin{array}{l}34.3 \% \\
(n=71)\end{array}$ & $\begin{array}{l}35.7 \% \\
(n=74)\end{array}$ & $\begin{array}{l}3.4 \% \\
(n=7)\end{array}$ \\
\hline $\begin{array}{l}\text { 7. I've been accepting the reality of the fact that it has } \\
\text { happened }\end{array}$ & $\begin{array}{l}9.2 \% \\
(n=19)\end{array}$ & $\begin{array}{l}22.7 \% \\
(n=47)\end{array}$ & $\begin{array}{l}37.2 \% \\
(n=77)\end{array}$ & $\begin{array}{l}28 \% \\
(n=58)\end{array}$ & $\begin{array}{l}2.9 \% \\
(n=6)\end{array}$ \\
\hline 8. I've been learning to live with it & $\begin{array}{l}6.8 \% \\
(n=14)\end{array}$ & $\begin{array}{l}21.3 \% \\
(n=47)\end{array}$ & $\begin{array}{l}34.8 \% \\
(n=72)\end{array}$ & $\begin{array}{l}34.3 \% \\
(n=71)\end{array}$ & $\begin{array}{l}2.9 \% \\
(n=6)\end{array}$ \\
\hline 9. I've been making jokes about it & $\begin{array}{l}16.9 \% \\
(n=35)\end{array}$ & $\begin{array}{l}25.1 \% \\
(\mathrm{n}=52)\end{array}$ & $\begin{array}{l}28 \% \\
(n=58)\end{array}$ & $\begin{array}{l}27.1 \% \\
(n=56)\end{array}$ & $\begin{array}{l}2.9 \% \\
(n=6)\end{array}$ \\
\hline 10. I've been making fun of the situation & $\begin{array}{l}25.6 \% \\
(n=53)\end{array}$ & $\begin{array}{l}28 \% \\
(n=58)\end{array}$ & $\begin{array}{l}20.8 \% \\
(n=43)\end{array}$ & $\begin{array}{l}21.7 \% \\
(n=45)\end{array}$ & $\begin{array}{l}3.9 \% \\
(n=8)\end{array}$ \\
\hline $\begin{array}{l}\text { 11. I've been trying to find comfort in my religion or } \\
\text { spiritual beliefs }\end{array}$ & $\begin{array}{l}40.1 \% \\
(n=83)\end{array}$ & $\begin{array}{l}21.3 \% \\
(n=44)\end{array}$ & $\begin{array}{l}13.5 \% \\
(n=28)\end{array}$ & $\begin{array}{l}18.8 \% \\
(n=39)\end{array}$ & $\begin{array}{l}6.3 \% \\
(n=13)\end{array}$ \\
\hline 12. I've been praying or meditating & $\begin{array}{l}42.5 \% \\
(n=88)\end{array}$ & $\begin{array}{l}23.2 \% \\
(n=48)\end{array}$ & $\begin{array}{l}12.6 \% \\
(n=26)\end{array}$ & $\begin{array}{l}15.5 \% \\
(n=32)\end{array}$ & $\begin{array}{l}6.3 \% \\
(n=13)\end{array}$ \\
\hline 13. I've been getting emotional support from others & $\begin{array}{l}18.4 \% \\
(n=38)\end{array}$ & $\begin{array}{l}29.5 \% \\
(n=61)\end{array}$ & $\begin{array}{l}32.9 \% \\
(n=68)\end{array}$ & $\begin{array}{l}21.7 \% \\
(n=45)\end{array}$ & $\begin{array}{l}3.4 \% \\
(n=7)\end{array}$ \\
\hline $\begin{array}{l}\text { 14. I've been getting comfort and understanding from } \\
\text { someone }\end{array}$ & $\begin{array}{l}14.5 \% \\
(n=30)\end{array}$ & $\begin{array}{l}29.5 \% \\
(n=61)\end{array}$ & $\begin{array}{l}30.9 \% \\
(n=64)\end{array}$ & $\begin{array}{l}21.7 \% \\
(n=45)\end{array}$ & $\begin{array}{l}3.4 \% \\
(n=7)\end{array}$ \\
\hline $\begin{array}{l}\text { 15. I've been trying to get advice or help from other } \\
\text { people about what to do }\end{array}$ & $\begin{array}{l}19.8 \% \\
(n=41)\end{array}$ & $\begin{array}{l}29 \% \\
(n=60)\end{array}$ & $\begin{array}{l}27.1 \% \\
(n=56)\end{array}$ & $\begin{array}{l}18.4 \% \\
(n=38)\end{array}$ & $\begin{array}{l}5.8 \% \\
(n=12)\end{array}$ \\
\hline 16. I've been getting help and advice from other people & $\begin{array}{l}19.3 \% \\
(n=40)\end{array}$ & $\begin{array}{l}34.8 \% \\
(n=72)\end{array}$ & $\begin{array}{l}24.6 \% \\
(n=51)\end{array}$ & $\begin{array}{l}16.4 \% \\
(n=34)\end{array}$ & $\begin{array}{l}4.8 \% \\
(n=10)\end{array}$ \\
\hline $\begin{array}{l}\text { 17. I've been turning to work or other activities to take } \\
\text { my mind off things }\end{array}$ & $\begin{array}{l}18.8 \% \\
(n=39)\end{array}$ & $\begin{array}{l}30 \% \\
(n=62)\end{array}$ & $\begin{array}{l}30 \% \\
(n=62)\end{array}$ & $\begin{array}{l}17.9 \% \\
(n=37)\end{array}$ & $\begin{array}{l}3.4 \% \\
(n=7)\end{array}$ \\
\hline
\end{tabular}




\begin{tabular}{|c|c|c|c|c|c|}
\hline $\begin{array}{l}\text { 18. I've been doing something to think about it less, such } \\
\text { as going to movies, watching TV, reading, daydreaming, } \\
\text { sleeping, or shopping }\end{array}$ & $\begin{array}{l}15 \% \\
(n=31)\end{array}$ & $\begin{array}{l}29.5 \% \\
(n=61)\end{array}$ & $\begin{array}{l}31.4 \% \\
(n=65)\end{array}$ & $\begin{array}{l}20.3 \% \\
(n=42)\end{array}$ & $\begin{array}{l}3.9 \% \\
(\mathrm{n}=8)\end{array}$ \\
\hline 19. I've been saying to myself 'this isn't real' & $\begin{array}{l}81.2 \% \\
(\mathrm{n}=168)\end{array}$ & $\begin{array}{l}7.7 \% \\
(n=16)\end{array}$ & $\begin{array}{l}4.3 \% \\
(n=9)\end{array}$ & $\begin{array}{l}2.4 \% \\
(\mathrm{n}=5)\end{array}$ & $\begin{array}{l}4.3 \% \\
(n=9)\end{array}$ \\
\hline 20. I've been refusing to believe that it has happened & $\begin{array}{l}80.2 \% \\
(n=166)\end{array}$ & $\begin{array}{l}9.7 \% \\
(n=20)\end{array}$ & $\begin{array}{l}3.4 \% \\
(n=7)\end{array}$ & $\begin{array}{l}1 \% \\
(n=2)\end{array}$ & $\begin{array}{l}5.8 \% \\
(n=12)\end{array}$ \\
\hline $\begin{array}{l}\text { 21. I've been saying things to let my unpleasant feelings } \\
\text { escape }\end{array}$ & $\begin{array}{l}47.8 \% \\
(n=99)\end{array}$ & $\begin{array}{l}27.1 \% \\
(n=56)\end{array}$ & $\begin{array}{l}15 \% \\
(n=31)\end{array}$ & $\begin{array}{l}5.3 \% \\
(n=11)\end{array}$ & $\begin{array}{l}4.8 \% \\
(n=10)\end{array}$ \\
\hline 22. I've been expressing my negative feelings & $\begin{array}{l}23.2 \% \\
(n=48)\end{array}$ & $\begin{array}{l}39.1 \% \\
(n=81)\end{array}$ & $\begin{array}{l}24.6 \% \\
(n=51)\end{array}$ & $\begin{array}{l}8.7 \% \\
(n=18)\end{array}$ & $\begin{array}{l}4.3 \% \\
(n=9)\end{array}$ \\
\hline $\begin{array}{l}\text { 23. I've been using alcohol or other drugs to make myself } \\
\text { feel better }\end{array}$ & $\begin{array}{l}66.7 \% \\
(n=138)\end{array}$ & $\begin{array}{l}22.2 \% \\
(n=46)\end{array}$ & $\begin{array}{l}6.3 \% \\
(n=13)\end{array}$ & $\begin{array}{l}.5 \% \\
(n=1)\end{array}$ & $\begin{array}{l}4.3 \% \\
(n=9)\end{array}$ \\
\hline $\begin{array}{l}\text { 24. I've been using alcohol or other drugs to help me get } \\
\text { through it }\end{array}$ & $\begin{array}{l}72.5 \% \\
(n=150)\end{array}$ & $\begin{array}{l}15.5 \% \\
(n=32)\end{array}$ & $\begin{array}{l}7.2 \% \\
(n=15)\end{array}$ & $\begin{array}{l}.5 \% \\
(n=1)\end{array}$ & $\begin{array}{l}4.3 \% \\
(n=9)\end{array}$ \\
\hline 25. I've been giving up trying to deal with it & $\begin{array}{l}64.3 \% \\
(n=133)\end{array}$ & $\begin{array}{l}20.8 \% \\
(n=43)\end{array}$ & $\begin{array}{l}7.7 \% \\
(n=16)\end{array}$ & $\begin{array}{l}.9 \% \\
(n=4)\end{array}$ & $\begin{array}{l}5.3 \% \\
(n=11)\end{array}$ \\
\hline 26. I've been giving up attempt to cope & $\begin{array}{l}70.5 \% \\
(n=176)\end{array}$ & $\begin{array}{l}19.8 \% \\
(n=41)\end{array}$ & $\begin{array}{l}2.9 \% \\
(n=6)\end{array}$ & $\begin{array}{l}1.4 \% \\
(n=3)\end{array}$ & $\begin{array}{l}5.3 \% \\
(n=11)\end{array}$ \\
\hline 27. I've been criticizing myself & $\begin{array}{l}30 \% \\
(n=62)\end{array}$ & $\begin{array}{l}32.4 \% \\
(n=67)\end{array}$ & $\begin{array}{l}21.7 \% \\
(n=45)\end{array}$ & $\begin{array}{l}11.1 \% \\
(n=23)\end{array}$ & $\begin{array}{l}4.8 \% \\
(n=10)\end{array}$ \\
\hline 28. I've been blaming myself for things that happened & $\begin{array}{l}49.8 \% \\
(n=103)\end{array}$ & $\begin{array}{l}23.2 \% \\
(n=48)\end{array}$ & $\begin{array}{l}14 \% \\
(n=29)\end{array}$ & $\begin{array}{l}9.2 \% \\
(n=19)\end{array}$ & $\begin{array}{l}3.9 \% \\
(n=8)\end{array}$ \\
\hline
\end{tabular}

Legend: 1 - I haven't been doing this at all; 2 - (no specific word assignment) 3 - (no specific word assignment); 4 - I've been doing this a lot; 5 - No Response 
Table D16. Descriptive Statistics for gender x class rank for Academic or work concerns.

\begin{tabular}{lccc} 
& Gender & Class Rank & Mean, SD, $(\mathrm{n})$ \\
\hline Academic or work concerns & Male & $1^{\text {st }}$ year & $6.00 \pm 1.414(\mathrm{n}=24)$ \\
& & $2^{\text {nd }}$ year & $6.04 \pm 1.899(\mathrm{n}=57)$ \\
& Female & $1^{\text {st }}$ year & $6.00 \pm 1.661(\mathrm{n}=51)$ \\
& $2^{\text {nd }}$ year & $6.38 \pm 1.710(\mathrm{n}=71)$ \\
& Total & $1^{\text {st }}$ year & $5.99 \pm 1.560(\mathrm{n}=77)$ \\
& $2^{\text {nd }}$ year & $6.23 \pm 1.798(\mathrm{n}=128)$ \\
\hline
\end{tabular}

Table D17. Descriptive Statistics for gender x class rank for Social/Personal Relationships.

\begin{tabular}{llll} 
& Gender & Class Rank & Mean, SD, $(\mathrm{n})$ \\
\hline Social/Personal Relationships & Male & $1^{\text {st }}$ year & $4.58 \pm 1.816(\mathrm{n}=24)$ \\
& & $2^{\text {nd }}$ year & $4.37 \pm 1.905(\mathrm{n}=57)$ \\
& Female & $1^{\text {st }}$ year & $4.98 \pm 2.140(\mathrm{n}=51)$ \\
& $2^{\text {nd }}$ year & $4.30 \pm 1.824(\mathrm{n}=71)$ \\
& Total & $1^{\text {st }}$ year & $4.83 \pm 2.022(\mathrm{n}=77)$ \\
& & $2^{\text {nd }}$ year & $4.33 \pm 1.853(\mathrm{n}=128)$ \\
\hline
\end{tabular}

Table D18. Descriptive Statistics for gender x class rank for Financial Concerns.

\begin{tabular}{lccc}
\hline Gender & Class Rank & Mean, $S D,(\mathrm{n})$ \\
\hline Financial Concerns & Male & $1^{\text {st }}$ year & $5.83 \pm 1.633(\mathrm{n}=24)$ \\
& $2^{\text {nd }}$ year & $5.77 \pm 2.096(\mathrm{n}=57)$ \\
& Female & $1^{\text {st }}$ year & $6.14 \pm 2.069(\mathrm{n}=51)$ \\
& $2^{\text {nd }}$ year & $6.59 \pm 2.155(\mathrm{n}=71)$ \\
& Total & $1^{\text {st }}$ year & $6.01 \pm 1.943(\mathrm{n}=77)$ \\
& $2^{\text {nd }}$ year & $6.23 \pm 2.160(\mathrm{n}=128)$ \\
\hline
\end{tabular}

Table D19. Descriptive Statistics for gender x class rank for Overall level of stress.

\begin{tabular}{lccc}
\hline & Gender & Class Rank & Mean, $\mathrm{SD},(\mathrm{n})$ \\
\hline Overall level of Stress & Male & $1^{\text {st }}$ year & $5.04 \pm 1.706(\mathrm{n}=24)$ \\
& $2^{\text {nd }}$ year & $4.44 \pm 1.955(\mathrm{n}=57)$ \\
& Female & $1^{\text {st }}$ year & $5.35 \pm 2.018(\mathrm{n}=51)$ \\
& $2^{\text {nd }}$ year & $5.70 \pm 1.967(\mathrm{n}=71)$ \\
& Total & $1^{\text {st }}$ year & $5.23 \pm 1.898(\mathrm{n}=77)$ \\
& $2^{\text {nd }}$ year & $5.14 \pm 2.053(\mathrm{n}=128)$ \\
\hline
\end{tabular}


Table D20. Descriptive Statistics for gender x class rank for Overall stress this year compared to last year.

\begin{tabular}{lccc}
\hline & Gender & Class Rank & Mean, SD, $(\mathrm{n})$ \\
\hline $\begin{array}{l}\text { Overall Stress this year } \\
\text { compared to last year }\end{array}$ & Male & $1^{\text {st }}$ year & $5.71 \pm 1.967(\mathrm{n}=24)$ \\
& Female & $2^{\text {nd }}$ year & $5.02 \pm 2.109(\mathrm{n}=57)$ \\
& $1^{\text {st }}$ year & $5.82 \pm 2.224(\mathrm{n}=51)$ \\
& Total & $2^{\text {nd }}$ year & $5.77 \pm 1.921(\mathrm{n}=71)$ \\
& $1^{\text {st }}$ year & $5.75 \pm 2.116(\mathrm{n}=77)$ \\
& $2^{\text {nd }}$ year & $5.44 \pm 2.034(\mathrm{n}=128)$ \\
\hline & & \\
Table D21. Descriptive Statistics for Gender & & \\
Variable (Stress) & Gender & Mean, SD, $(\mathrm{n})$ \\
\hline academic or work concerns & male & $5.99 \pm 1.781(\mathrm{n}=82)$ \\
& female & $6.21 \pm 1.690(\mathrm{n}=123)$ \\
social/personal relationships & male & $4.43 \pm 1.859(\mathrm{n}=82)$ \\
& female & $4.57 \pm 1.980(\mathrm{n}=123)$ \\
financial concerns & male & $5.80 \pm 1.953(\mathrm{n}=82)$ \\
& female & $6.38 \pm 2.125(\mathrm{n}=123)$ \\
overall level of stress & male & $4.61 \pm 1.884(\mathrm{n}=82)$ \\
& female & $5.54 \pm 1.985(\mathrm{n}=123)$ \\
overall level of stress this yr to last yr & male & $5.20 \pm 2.081(\mathrm{n}=82)$ \\
& female & $5.79 \pm 2.038(\mathrm{n}=123)$ \\
\hline
\end{tabular}

Table D22. Descriptive Statistics for First year and Second year graduate assistant

Variable (Stress)

academic or work concerns

social/personal relationships

financial concerns

overall level of stress

overall level of stress this year to last yr
Class Rank

$1^{\text {st }} \mathrm{yr}$

$2^{\text {nd }} \mathrm{yr}$

$1^{\text {st }} \mathrm{yr}$

$2^{\text {nd }} \mathrm{yr}$

$1^{\text {st }} \mathrm{yr}$

$2^{\text {nd }} \mathrm{yr}$

$1^{\text {st }} \mathrm{yr}$

$2^{\text {nd }} \mathrm{yr}$

$1^{\text {st }} \mathrm{yr}$

$2^{\text {nd }} \mathrm{yr}$
Mean, SD, (n)

$5.99 \pm 1.560(\mathrm{n}=77)$

$6.23 \pm 1.798(\mathrm{n}=128)$

$4.83 \pm 2.022(\mathrm{n}=77)$

$4.33 \pm 1.853(\mathrm{n}=128)$

$6.01 \pm 1.943(\mathrm{n}=77)$

$6.23 \pm 2.160(\mathrm{n}=128)$

$5.23 \pm 1.898(\mathrm{n}=77)$

$5.14 \pm 2.053(\mathrm{n}=128)$

$5.75 \pm 2.116(\mathrm{n}=77)$

$5.44 \pm 2.034(\mathrm{n}=128)$ 
Table D23. Descriptive Statistics for Gender and remaining QSQ stressors

\begin{tabular}{|c|c|c|}
\hline Variable (Stress) & Gender & Mean, SD, (n) \\
\hline \multicolumn{3}{|l|}{ Psychological stress } \\
\hline \multirow[t]{2}{*}{ Family concerns } & Male & $4.06 \pm 2.002(n=82)$ \\
\hline & Female & $4.08 \pm 1.974(n=123)$ \\
\hline \multirow[t]{2}{*}{ Self-image } & Male & $3.82 \pm 1.906(\mathrm{n}=82)$ \\
\hline & Female & $4.71 \pm 2.138(\mathrm{n}=123)$ \\
\hline \multirow[t]{2}{*}{ Day to Day Hassles } & Male & $4.72 \pm 2.044(\mathrm{n}=82)$ \\
\hline & Female & $5.12 \pm 1.944(n=123)$ \\
\hline \multirow[t]{2}{*}{ Anger, hostility } & Male & $4.12 \pm 2.033(\mathrm{n}=82)$ \\
\hline & Female & $4.55 \pm 1.997(\mathrm{n}=123)$ \\
\hline \multirow[t]{2}{*}{ Forgetfulness, mental inefficiency } & Male & $4.57 \pm 2.120(\mathrm{n}=82)$ \\
\hline & Female & $5.07 \pm 2.569(\mathrm{n}=123)$ \\
\hline \multirow[t]{2}{*}{ Avoidance behavior } & Male & $4.35 \pm 2.235(\mathrm{n}=82)$ \\
\hline & Female & $4.77 \pm 2.508(\mathrm{n}=123)$ \\
\hline \multicolumn{3}{|l|}{ Physical Stress } \\
\hline \multirow{2}{*}{ Health concerns } & Male & $3.88 \pm 1.914(\mathrm{n}=82)$ \\
\hline & Female & $4.18 \pm 2.254(\mathrm{n}=123)$ \\
\hline \multirow[t]{2}{*}{ Sexual concerns } & Male & $3.65 \pm 2.051(\mathrm{n}=82)$ \\
\hline & Female & $3.10 \pm 2.186(\mathrm{n}=123)$ \\
\hline \multirow{2}{*}{ Feelings of depression } & Male & $3.24 \pm 2.231(\mathrm{n}=82)$ \\
\hline & Female & $4.20 \pm 2.485(\mathrm{n}=123)$ \\
\hline \multirow[t]{2}{*}{ Apprehension, fears } & Male & $3.98 \pm 1.931(\mathrm{n}=82)$ \\
\hline & Female & $4.98 \pm 2.135(n=123)$ \\
\hline \multirow[t]{2}{*}{ Muscle tension, headaches } & Male & $3.87 \pm 2.413(\mathrm{n}=82)$ \\
\hline & Female & $5.04 \pm 2.543(n=123)$ \\
\hline \multirow[t]{2}{*}{ Indigestion, stomachache } & Male & $2.73 \pm 2.363(\mathrm{n}=82)$ \\
\hline & Female & $3.32 \pm 2.809(\mathrm{n}=123)$ \\
\hline \multirow[t]{2}{*}{ Tics, tremors, muscle spasms } & Male & $2.44 \pm 2.578(\mathrm{n}=82)$ \\
\hline & Female & $2.56 \pm 2.843(\mathrm{n}=123)$ \\
\hline \multirow[t]{2}{*}{ Sleeping disturbances, insomnia } & Male & $3.88 \pm 2.501(\mathrm{n}=82)$ \\
\hline & Female & $4.71 \pm 2.598(n=123)$ \\
\hline \multirow[t]{2}{*}{ Disordered eating } & Male & $3.06 \pm 2.654(\mathrm{n}=82)$ \\
\hline & Female & $4.02 \pm 2.723(\mathrm{n}=123)$ \\
\hline \multirow[t]{2}{*}{ Excessive drinking and/or drug use } & Male & $3.84 \pm 2.755(\mathrm{n}=82)$ \\
\hline & Female & $3.33 \pm 2.765(\mathrm{n}=123)$ \\
\hline \multirow[t]{2}{*}{ Hypertension } & Male & $2.95 \pm 2.815(\mathrm{n}=82)$ \\
\hline & Female & $2.59 \pm 3.043(\mathrm{n}=123)$ \\
\hline \multirow{2}{*}{ Acne, eczema, hives } & Male & $2.67 \pm 2.653(\mathrm{n}=82)$ \\
\hline & Female & $3.52 \pm 2.864(n=123)$ \\
\hline
\end{tabular}


Table D24. Descriptive Statistics for $1_{-}^{\text {st }}$ year $2^{\text {nd }}$ year graduate assistant and remaining QSQ stressors

Variable (Stress) Class Rank Mean, SD, (n)

Psychological stress

Family concerns

$1^{\text {st }}$ year

$4.10 \pm 1.951(\mathrm{n}=77)$

Self-image

$2^{\text {nd }}$ year

$4.06 \pm 1.995(\mathrm{n}=128)$

Day to Day Hassles

$1^{\text {st }}$ year

$4.51 \pm 2.150(\mathrm{n}=77)$

$2^{\text {nd }}$ year

$4.26 \pm 2.055(\mathrm{n}=128)$

$1^{\text {st }}$ year

$4.97 \pm 1.980(\mathrm{n}=77)$

Anger, hostility

$2^{\text {nd }}$ year

$4.93 \pm 1.997(\mathrm{n}=128)$

$1^{\text {st }}$ year

$4.25 \pm 2.225(\mathrm{n}=77)$

Forgetfulness, mental inefficiency

$2^{\text {nd }}$ year

$4.43 \pm 1.902(\mathrm{n}=128)$

$1^{\text {st }}$ year

$5.32 \pm 2.359(\mathrm{n}=77)$

Avoidance behavior

$2^{\text {nd }}$ year

$4.58 \pm 2.393(n=128)$

$1^{\text {st }}$ year

$4.69 \pm 2.483(\mathrm{n}=77)$

$2^{\text {nd }}$ year

$4.55 \pm 2.377(\mathrm{n}=128)$

Physical Stress

Health concerns

$1^{\text {st }}$ year

$3.81 \pm 1.785(\mathrm{n}=77)$

Sexual concerns

$2^{\text {nd }}$ year

$4.18 \pm 2.312(\mathrm{n}=128)$

$1^{\text {st }}$ year

$3.56 \pm 2.161(\mathrm{n}=77)$

$2^{\text {nd }}$ year

$3.11 \pm 2.119(\mathrm{n}=128)$

Feelings of depression

$1^{\text {st }}$ year

$4.04 \pm 2.419(\mathrm{n}=77)$

$2^{\text {nd }}$ year

$3.68 \pm 2.430(\mathrm{n}=128)$

Apprehension, fears

$1^{\text {st }}$ year

$4.81 \pm 2.084(\mathrm{n}=77)$

Muscle tension, headaches

$2^{\text {nd }}$ year

$4.49 \pm 2.141(\mathrm{n}=128)$

$1^{\text {st }}$ year

$4.47 \pm 2.469(\mathrm{n}=77)$

$2^{\text {nd }}$ year

$4.65 \pm 2.610(\mathrm{n}=128)$

Indigestion, stomachache

$1^{\text {st }}$ year

$2.83 \pm 2.347(\mathrm{n}=77)$

$2^{\text {nd }}$ year

$3.23 \pm 2.813(\mathrm{n}=128)$

Tics, tremors, muscle spasms

$1^{\text {st }}$ year

$2.43 \pm 2.668(\mathrm{n}=77)$

$2^{\text {nd }}$ year

$2.62 \pm 2.859(\mathrm{n}=128)$

Sleeping disturbances, insomnia

$1^{\text {st }}$ year

$4.51 \pm 2.516(n=77)$

$2^{\text {nd }}$ year

$4.27 \pm 2.637(\mathrm{n}=128)$

Disordered eating

$1^{\text {st }}$ year

$3.86 \pm 2.684(\mathrm{n}=77)$

$2^{\text {nd }}$ year

$3.59 \pm 2.813(\mathrm{n}=128)$

Excessive drinking and/or drug use

$1^{\text {st }}$ year

$3.47 \pm 2.542(\mathrm{n}=77)$

Hypertension

$2^{\text {nd }}$ year

$3.52 \pm 2.916(\mathrm{n}=128)$

$1^{\text {st }}$ year

$2.86 \pm 3.111(\mathrm{n}=77)$

$2^{\text {nd }}$ year

$2.70 \pm 2.933(\mathrm{n}=128)$

Acne, eczema, hives

$1^{\text {st }}$ year

$3.36 \pm 2.911(\mathrm{n}=77)$

$2^{\text {nd }}$ year

$3.05 \pm 2.758(n=128)$ 
Table D25. Between Subjects MANOVA for the Quick Stress Questionnaire

\begin{tabular}{llllll}
\hline & Stress & F value & P & ES & $\beta$ \\
\hline Gender & & & & & \\
& academic or work concerns & .531 & .589 & .005 & .137 \\
& social/personal concerns & .188 & .829 & .002 & .079 \\
& financial concerns & .413 & .662 & .004 & .116 \\
& overall level of stress & .285 & .752 & .003 & .095 \\
& overall stress this yr to last yr & .844 & .431 & .008 & .194 \\
& & & & & \\
$1^{\text {st }}$ yr or $2^{\text {nd }}$ yr & & & & \\
& & 1.843 & .161 & .018 & .381 \\
& academic or work concerns & 1.431 & .241 & .014 & .304 \\
& social/personal concerns & .282 & .755 & .003 & .094 \\
& financial concerns & .415 & .661 & .004 & .117 \\
& overall level of stress & 1.241 & .291 & .012 & .268 \\
& overall stress this yr to last yr & & & & \\
Gender \& & & & & & \\
$1^{\text {st }}$ yr or 2 & yr & & & & \\
& academic or work concerns & .480 & .620 & .005 & .128 \\
& social/personal concerns & .398 & .672 & .004 & .114 \\
& financial concerns & 1.104 & .334 & .011 & .242 \\
& overall level of stress & 1.355 & .260 & .013 & .290 \\
& overall stress this yr to last yr & .651 & .523 & .006 & .158 \\
\hline
\end{tabular}

Legend: $\mathrm{P}=$ level of significance; $\mathrm{ES}=$ effect size; $\beta=$ Power 


\section{APPENDIX E}

\section{RECOMMENDATIONS FOR FUTURE RESEARCH}

1. This study could be done in October when students are under the highest amount of stress.

2. The study may also be sent out during two distinct time periods, such as in October and then again in March when higher stress levels are experienced

3. Add a question in demographics whether those who exercised are less stressed than those who do not have time. This will help to see the role exercise plays in stress management. 


\section{ADDITIONAL REFERENCES}

37. Gould D, Finch LM, Jackson SA. Coping strategies used by national champion figure skaters. Res Q Exerc Sport. 1993;64:453-468.

38. Maslach C, Jackson SE. The measurement of experiencing burnout. J Occupational Behavior. 1981;2:99-113.

39. Bernier D. A study of coping: successful recovery from severe burnout and other reactions to severe work-related stress. Work Stress. 1998;12:50-65.

40. Misra R, McKean M, West S, Russo T. Academic stress of college students: comparison of student and faculty perceptions. Coll Stu J. 2000;34(2):236-246.

41. Saipanish R. Stress among medical students in a Thai medical school. Medical Teacher. 2003;25(5):502-506. 